\title{
8Cl-cAMP modifies the balance between PKAR1 and PKAR2 and modulates the cell cycle, growth and apoptosis in human adrenocortical H295R cells
}

\author{
Zhor Bouizar $^{1,2}$, Bruno Ragazzon ${ }^{1,2}$, Lucie Viou ${ }^{1,2}$, Mariuccia Hortane ${ }^{1,2}$, \\ Jerôme Bertherat ${ }^{1,2,3}$ and Marthe Rizk-Rabin ${ }^{1,2}$ \\ ${ }^{1}$ Institut Cochin, Université Paris Descartes, CNRS (UMR 8104), ${ }^{2}$ INSERM, U567 and ${ }^{3}$ Service d'Endocrinologie, Groupe Hospitalier Cochin-St-Vincent de Paul, \\ 27 rue du Fg Saint-Jacques, 75014 Paris, France \\ (Correspondence should be addressed to M Rizk-Rabin; Email: marthe.rizk@inserm.fr)
}

\begin{abstract}
Various types of protein kinase A (PKA) alterations have been observed in adrenocortical tumours and Carney complex (CNC). PKA is a heterotetramer of two regulatory and two catalytic subunits. The R1A and R2B proteins are the most abundant regulatory subunits in endocrine tissues. A decrease in R2B protein levels has been observed in adrenal adenoma, whereas tumours from patients with CNC display a decrease in R1A protein levels. Dysregulation of the balance between R1A and R2B may thus be involved in adrenal tumourigenesis. We investigated the impact of the differences in the balance of PKA subunits on cell growth using specific cAMP analogues. We assessed the effects of 8-chloroadenosine-cAMP (8Cl-cAMP), a site-selective activator of PKA R2B, in H295R adrenocortical cells. 8Cl-cAMP stimulated PKA activity, decreased R1A levels and increased R2B levels. It had no cytotoxic effects, initially stimulating DNA synthesis and then inducing apoptosis by disrupting $\mathrm{G}_{2} / \mathrm{M}$ progression. We observed an initial accumulation of cells in the $S$ phase, translocation of cyclin $A$ to the nucleus, CDK2 activation, sustained DNA synthesis and proliferating cell nuclear antigen accumulation. Cell cycle arrest in the $G_{2}$ phase was parallel with the accumulation of cyclin $B$ and the inactivation of CDC2 kinase. The 8CPT-cAMP, which activates the R2B subunit, had similar effects. R2B silencing reduced the apoptosis induced by tumour necrosis factor $\alpha$ and transforming growth factor $\beta$. Thus, $R 2 B$ is a key regulator of proliferation/differentiation in H295R cell line along with the complex balance between the PKA subunits. Activation of PKA R2B and dysregulation of the R1A/R2B balance regulate cell cycle progression and apoptosis in adrenocortical cells by modulating cyclin production and cyclin-dependent kinase activities.
\end{abstract}

Journal of Molecular Endocrinology (2010) 44, 331-347

\section{Introduction}

Aberrant cAMP signalling has been linked to adrenocortical and other tumours, mostly to endocrine tumours (Bertherat 2001, Bossis \& Stratakis 2004). Based on the notion that proliferation, differentiation and steroid synthesis are principally dependent on ACTH-induced cAMP generation in the adrenal cortex, it has been suggested that changes in the cAMP cascade may result in the activation of cortisol synthesis and secretion and the development of adrenocortical neoplasia. Many defects downstream from cAMP production have been identified in adrenocrotical tumours (Groussin et al. 2000, Rosenberg et al. 2002, Horvath et al. 2006, 2008, Libe et al. 2008), but their effects on proliferation and differentiation remain unclear. Among these defects, the PRKAR1A alteration has a wide implication for the understanding of the cAMP signalling in adrenocortical tumours (Groussin et al. 2002a).
A high frequency of heterozygous inactivating germline mutations of the PRKAR1A gene has been reported in patients with Carney complex (CNC; Kirschner et al. 2000, Veugelers et al. 2004), which is characterised by spotty skin pigmentation (lentiginosis), endocrine hyperactivity with primary pigmented nodular adrenocortical disease (PPNAD) and cardiac myxoma (Carney et al. 1985, Groussin et al. 2002a,b, 2006). Somatic PRKAR1A mutations have been demonstrated in sporadic secreting adrenocortical adenomas with clinical, hormonal and pathological characteristics similar to those of PPNAD (Bertherat et al. 2003). Moreover, in vitro studies have indicated that PRKAR1A gene mutation (non-sense mRNA or truncated R1A) stimulates protein kinase A (PKA) activity (Groussin et al. 2002a,b, 2006). However, the relation of PKA type 1 and tumorigenesis in endocrine tumours is not exclusively due to PRKARIA gene mutation. The growth of several endocrine tumours is associated with the absence of R1A or very low concentrations of 
this subunit (Griffin et al. 2004a,b). Indeed, tumoural pituitary cells are characterised by low or absent expression of the RIA subunit protein, and this is probably due to proteasome-dependent protein degradation (Yamasaki et al. 2003). In addition, the downregulation of PRKAR1A expression by up to $70 \%$ in transgenic mouse tissues and embryonic fibroblasts results in concomitant increases in PKA kinase activity, cell proliferation and tumour formation (Griffin et al. 2004a,b, Veugelers et al. 2004). Moreover, we have shown recently that inactivating PRKAR1A gene dysregulated cAMP pathway and reduced transforming growth factor $\beta$ (TGF $\beta$ or TGFB1)-induced apoptosis by inhibiting SMAD3 expression in the human adrenocortical cell line (H295R; Ragazzon et al. 2009). These results suggest that the PKA type 1 may be considered as a tumour suppressor gene and as one of the key players in the development of adrenocortical tumours.

By contrast, the increase in PKA R1A levels has been associated with other types of human cancer tissues and cell lines, including retinoblastoma, breast cancers, malignant osteoblasts and serous ovarian tumours (Livesey et al. 1982, Miller et al. 1993, Stubbs et al. 1996, McDaid et al. 1999, Bossis \& Stratakis 2004). Thus, based on the upregulation of R1A in several cancers, studies show that inhibition of R1A expression through antisense oligonucleotides (Nesterova et al. 2000, Cho-Chung 2004, Cho-Chung \& Nesterova 2005) results in the growth arrest of several tumour cell lines. PKA RIA may be considered as an oncogene in these cancers (Nesterova \& Cho-Chung 2000, Cheadle et al. 2008).

PRKAR1A could act as a tumour suppressor gene and/or an oncogene, depending on the tumour and cell types. However, PKA holoenzyme is formed of two PKA regulatory subunits. The cAMP-dependent protein kinase type 1 (PKA 1) and cAMP-dependent protein kinase type 2 (PKA 2) have identical catalytic (C) subunits but different regulatory (R) subunits (R1 versus R2). The two subtypes are expressed in a balance of cell growth and differentiation (Cho et al. 2002, Bossis \& Stratakis 2004, Neary et al. 2004). Tumours from patients with CNC display a decrease in R1A protein levels and a compensatory activation of PKA type 2 (Bossis \& Stratakis 2004). Tumour lesions due to the downregulation of PRKAR1A expression in transgenic mice are associated with an increase in total PKA type 2 activities and an increase in PKA R2B protein levels (Griffin et al. 2004b). In adrenocortical adenoma, Mantovani et al. (2008a) and Vincent-Dejean et al. (2008) have demonstrated a defect in R2B expression and synthesis in benign, cortisol-secreting tumours. Lastly, many studies have shown that PKA regulatory subunit switching elicits tumour reversion or enhanced differentiation. Downregulation of PKA type 1 and overexpression of PKA type 2 in the PC3M prostate carcinoma cells lead to growth inhibition (Neary et al. 2004). By contrast, the imbalance in the PKA R1A/R2B ratio in favour of the $\mathrm{R} 2 \mathrm{~B}$ subunit induced by 8-chloroadenosine-cAMP (8Cl-cAMP) results in the cAMP-dependent proliferation of adenomatous somatotrophs (Lania et al. 2004). The overproduction of R2B in immortalised cell lines derived from a PPNAD bearing mutation inactivating PRKAR1A increases cell proliferation (Nesterova et al. 2008). Moreover, disrupting the balance of PKA subunits in the H295R by inactivation of PRKAR1A gene confers resistance to apoptosis (Ragazzon et al. 2009). However, no information is available on the PKA R2B involvement in this H295R cell line.

Specific cAMP analogues can preferentially activate the different PKA subtypes (Dyson et al. 2009). The regulatory subunits of PKA each possess two cAMPbinding sites positioned in tandem at the carboxyterminus of the protein. While highly conserved among all the regulatory subunits, these binding sites are not equivalent in their affinities for cAMP, and are distinguished as sites $\mathrm{A}$ and $\mathrm{B}$ within each regulatory subunit (Tasken \& Aandahl 2004).

To evaluate the stimulatory effects of PKA type 2 on adrenocortical tumours, we used 8Cl-cAMP, which is the most potent cAMP analogue that induces inhibition of cell growth in a variety of cancer cell types (Cho et al. 2002). 8Cl-cAMP binds to A and B sites of PKA R1 with a higher affinity than cAMP, thereby activating PKA type 1 , and decreasing the concentrations of R1A protein and mRNA as demonstrated in HL-60 leukaemia cells (Rohlff et al. 1993). 8Cl-cAMP also binds strongly to site B of PKA type 2, increasing R2B protein levels (Rohlff et al. 1993). We compared the 8Cl-cAMP effects with other selective cAMP analogues. 8CPT-CAMP is a cAMP analogue that is highly selective for site B of PKA type 2, and it does not bind to PKA type 1 (Knutsen et al. 1996). The Sp-diastereomer of AMP (SP-cAMP) is a potent, membrane-permeable activator of both cAMPdependent PKA type 1 and type 2. NCI-H295R, a steroid-secreting adrenocortical cell line, is the main model of human adrenocortical tumour (Groussin et al. 2000, Liu et al. 2004a, Rainey et al. 2004, Jaroenporn et al. 2008). The cell line is generally used to study the effects of antitumour drugs or steroid synthesis.

Thus, we have investigated the effects of these cAMP analogues on the cell cycle and the regulation of cyclins and cyclin-dependent kinase activiy in the H295R cells. We show that the stimulation of PKA activity with cAMP analogues, the dysregulation of the R1A/R2B balance and the increase in R2B have major impacts on the cell cycle, and allow to identify the precise role of R2B in this context. 


\section{Materials and methods}

\section{Materials}

We used various cAMP analogues, which are cAMP site selective of PKA type 1 or 2 , and act as phosphodiesterase (PDE)-resistant protein kinase activators. 8Cl-cAMP (Biolog, Life Science Institute) binds to A and B sites of PKA R1, thereby activating type 1 PKA and decreasing the concentrations of R1A protein and mRNA (Rohlff et al. 1993). 8Cl-cAMP also binds strongly to site B of PKA R2, activating type 2 PKA and increasing R2B protein levels (Rohlff et al. 1993). It inhibits the growth of several types of cancer cells. 8CPT-cAMP is a cAMP analogue that is highly selective for site $\mathrm{B}$ of PKA type 2 (8CPT-cAMP, Biolog, Life Science Institute; Knutsen et al. 1996). The SP-cAMP (Calbiochem by VWR International, Fontenay-sous-Bois cedex, France) is a potent, membrane-permeable activator of cAMPdependent PKA 1 and PKA 2.

\section{Cell culture}

Human H295R adrenocortical carcinoma cells were grown in DMEM-Ham's F12 supplemented with 50 units $/ \mathrm{ml}$ penicillin, $50 \mathrm{mg} / \mathrm{ml}$ streptomycin, $2 \%$ Ultroser G2 (Biosepra, Fremont, CA, USA) and ITS $(5 \mu \mathrm{g} / \mathrm{ml}$ insulin, $5 \mu \mathrm{g} / \mathrm{ml}$ transferrin and $5 \mathrm{ng} / \mathrm{ml}$ selenium; Sigma) at $37^{\circ} \mathrm{C}$ under an atmosphere of $5 \%$ carbon dioxide/95\% air (Groussin et al. 2000, Rizk-Rabin et al. 2008). Cells were cultured in 6-well plates $\left(350 \times 10^{3}\right.$ cells/well $)$ for protein extraction and 5-bromo-2'-deoxyuridine (BrdU) incorporation; in 12-well plates $\left(250 \times 10^{3}\right.$ cells $/$ well $)$ for cell cycle profile determination, synchronisation, proliferating cell nuclear antigen (PCNA) staining and apoptosis assays, and in 96-well plates $\left(10 \times 10^{3}\right.$ cells/well $)$ for MTT assays. Cells were allowed to attach for $48 \mathrm{~h}$, and were then incubated with the cAMP analogues for 4 or 7 days. Medium and drugs were replenished on days 3 and 5 .

Human embryonic kidney 293T (HEK293T) cells and MCF-7 cells were grown in DMEM supplemented with $10 \%$ FCS.

\section{MTT cell survival and BrdU incorporation}

The MTT assay is based on the conversion of the yellow tetrazolium salt MTT (Cell Titer 96 Non-Radioactive Cell Proliferation Assay, Promega) to purple formazan crystals by metabolically active cells. It provides an estimate of the number of viable cells (Rizk-Rabin $\mathrm{et} \mathrm{al}$. 2008). H295R cells were used to seed 96-well plates at a density of $10 \times 10^{3}$ cells, and were cultured for $48 \mathrm{~h}$. They were then incubated with the cAMP analogues, at the concentrations indicated in the figures, for $24 \mathrm{~h}$,
$48 \mathrm{~h}, 4$ or 7 days. The MTT reagents were used according to the manufacturer's recommendations. Optical absorbance was measured at $570 \mathrm{~nm}$ in a microplate reader. For BrdU incorporation, the cells were used to seed six-well plates, and were treated as described above. They were incubated with BrdU ( $10 \mu \mathrm{M}$; Sigma) for $6 \mathrm{~h}$ before each time point (days 2, 4, 6 and 7). Cells were then harvested, washed in PBS and fixed in $70 \%$ ethanol $(500 \mu \mathrm{l})$. For BrdU analysis, cells were centrifuged, rinsed twice in PBS, incubated with $2 \mathrm{M} \mathrm{HCl}$ at room temperature for $20 \mathrm{~min}$, collected by centrifugation, and washed twice in PBS and once in PBS $+0.5 \%$ Tween $+0.05 \% \mathrm{w} / \mathrm{v}$ BSA. They were then incubated with $20 \mu \mathrm{l}$ of monoclonal antiBrdU monoclonal FITC antibody for 20 min according to the manufacturer's instructions (BD Biosciences, Le Pont de Claix cedex, France). They were centrifuged, rinsed in PBS, suspended in $500 \mu \mathrm{l} \mathrm{PBS}$ supplemented with $50 \mu \mathrm{g} / \mathrm{ml}$ propidium iodide plus $100 \mu \mathrm{g} / \mathrm{ml}$ RNase A and analysed by flow cytometry using a FACscan (EPICS XL Coulter, Villepinte, France). Data were analysed with Multicycle software. All experiments were carried out three times. The histogram was constructed with at least 20000 cells.

\section{Western blotting}

Whole-cell protein lysates were obtained by extraction with RIPA lysis buffer containing $50 \mathrm{mM}$ Tris-HCl, $\mathrm{pH}$ $7 \cdot 5,1 \mathrm{mM}$ EDTA, $150 \mathrm{mM} \mathrm{NaCl}, 0 \cdot 1 \% \mathrm{v} / \mathrm{v}$ Nonidet P-40 (NP40), $1 \mathrm{mM}$ dithiothreitol (DTT), protease inhibitor cocktail (Roche), $1 \mathrm{mM}$ phenylmethylsulphonyl fluoride (PMSF), and anti-phosphatase inhibitor, $1 \mathrm{mM}$ sodium orthovanadate, and $1 \mathrm{mM}$ okadoic acid (Sigma). Cell cytosols were extracted by incubation for 5 min with buffer A containing $20 \mathrm{mM}$ HEPES, $\mathrm{pH} 7 \cdot 9$, $20 \mathrm{mM} \mathrm{NaCl}, 50 \mathrm{mM} \mathrm{NaF}$ and $0.5 \% \mathrm{v} / \mathrm{v} \mathrm{NP} 40$. Cells were scraped off and collected by centrifugation at $13000 \mathrm{~g}$ for $15 \mathrm{~min}$. The resulting supernatant was collected, and the nuclear fraction was obtained from the pellet by incubation with buffer $\mathrm{B}$, which contained $20 \mathrm{mM}$ HEPES, pH 7.9, $50 \mathrm{mM} \mathrm{NaF}, 200 \mathrm{mM}$ EDTA, $420 \mathrm{mM} \mathrm{NaCl}, 25 \% \mathrm{v} / \mathrm{v}$ glycerol and $1.5 \mathrm{mM} \mathrm{MgCl}_{2}$. Both buffers A and B were supplemented with protease inhibitor cocktail, $1 \mathrm{mM}$ PMSF and anti-phosphatase inhibitors as for the RIPA buffer. The nuclear pellet was incubated for $15 \mathrm{~min}$ and centrifuged, and the supernatant was collected. Equal amounts of protein, as determined with the Bio-Rad protein assay (Bio-Rad), were separated by electrophoresis in $10 \%$ SDS gels and transferred electrophoretically onto membranes. Western blotting was performed with primary mouse antibodies directed against R1A (1/250, Becton Dickinson Transduction Laboratories), R2A $(1 / 250)$ and R2B (1/1000), and catalytic subunits 
(1/1000; Santa Cruz Biotechnology, Tebu, France). The anti-cyclin E antibody was obtained from BD Biosciences. The anti-cyclin $\mathrm{A}$ and $\mathrm{B}$ antibodies $(1 / 200)$ and antibodies against the cyclin-dependent kinases CDK2 and CDC2 (listed as CDK1 in the HUGO Database)/p34 were obtained from Santa Cruz Biotechnology. We used anti- $\beta$-actin antibody $(1 / 2500$; Sigma) as a standard for cell lysates and anti-lamin A/C antibody (1/1000; Cell Signaling) as a standard for nuclear samples. The antigen-antibody complexes were visualised with appropriate secondary antibodies (Santa Cruz) by chemiluminescence detection (ECL kit, Amersham). The signals were digitised with the Gene Tool analysis system.

\section{Immunoprecipitation and histone kinase assay}

Cells were incubated with RIPA buffer for $30 \mathrm{~min}$ as described above. Cells were scraped off, sonicated twice at $40 \mathrm{~Hz}$ for $20 \mathrm{~s}$ each, and centrifuged for $10 \mathrm{~min}$ at $13000 \mathrm{~g}$, and the supernatant was collected. An aliquot of each sample (equivalent of $200 \mu \mathrm{g}$ total protein) was incubated with $2 \mu \mathrm{g}$ of specific anti-CDK2 or anti-CDC2 antibody, with gentle shaking, for at least $4 \mathrm{~h}$ at $4{ }^{\circ} \mathrm{C}$. Samples were then incubated with protein $G$ plus agarose $(20 \mu \mathrm{l})$ or protein A/G plus agarose $(20 \mu \mathrm{l}$; Santa Cruz) in RIPA buffer for $2 \mathrm{~h}$ for immunocomplex formation. The beads were collected by centrifugation, and washed three times with RIPA buffer and twice with kinase reaction buffer $(50 \mathrm{mM}$ Tris- $\mathrm{HCl}, \mathrm{pH} 7 \cdot 5$, $15 \mathrm{mM} \mathrm{MgCl}_{2}$ and $1 \mathrm{mM}$ DTT). Before in vitro kinase assays, the immunoprecipitated CDK2 and CDC2 were subjected to SDS-PAGE in $12.5 \%$ acrylamide gels and were electrophoretically transferred to membranes, which were incubated with antibodies against either CDK2 or CDC2. The antigen-antibody complexes were visualised as described above. For in vitro kinase assays, we measured CDK2- and CDC2-associated H1 kinase activities as described by Porter et al. (2001). The phosphorylated reaction products were resolved by SDS-PAGE in $12.5 \%$ acrylamide gels, and $\gamma^{-32} \mathrm{P}$ incorporation was visualised by autoradiography.

\section{Cell cycle distribution}

We seeded 12-well plates with the cells, which were cultured and then harvested, rinsed with PBS and fixed in $500 \mu \mathrm{l}$ of $70 \%$ ethanol. The cells were centrifuged, rinsed in PBS and suspended in $500 \mu \mathrm{l}$ of $50 \mu \mathrm{g} / \mathrm{ml}$ propidium iodide in PBS supplemented with $100 \mu \mathrm{g} / \mathrm{ml}$ RNase A. They were analysed by flow cytometry using a FACscan machine (EPICS XL Coulter). Data were analysed with Multicycle software. All experiments were carried out three times. Each histogram was constructed with at least 10000 cells (Rizk-Rabin et al. 2008).

\section{PCNA immunostaining}

Monoclonal phycoerythrin (PE)-conjugated antibody against PCNA was used as an essential marker for DNA synthesis. Cells fixed in $70 \%$ ethanol were centrifuged, washed in PBS and permeabilised by incubation for 5 min with Triton X-100 $(0 \cdot 25 \%)$. They were then incubated with $20 \mu \mathrm{l}$ FITC-conjugated antibody against PCNA overnight at $4{ }^{\circ} \mathrm{C} \quad(\mathrm{BD}$ Biosciences). PCNA staining was analysed by flow cytometry with a FACscan machine (EPICS XL Coulter; Beppu et al. 1994).

\section{Cell cycle synchronisation}

We used H295R cells to seed 12-well plates at a density of $150 \times 10^{3}$ cells/well. The cells were cultured for $24 \mathrm{~h}$ and then treated for $24 \mathrm{~h}$ with aphidicolin $(4 \mu \mathrm{g} / \mathrm{ml})$, an inhibitor of DNA synthesis (Sigma), or for $48 \mathrm{~h}$ with nocodazole $(10 \mu \mathrm{M})$, an anti-neoplastic agent interfering with microtubule polymerisation (Sigma). The cells were then washed three times with PBS and incubated in a medium with or without 8Cl-cAMP or 8CPT-cAMP for $6,12,24$ or $48 \mathrm{~h}$. Propidium iodide was added, and the distribution of cells in the various phases of the cell cycle was analysed by flow cytometry (FACscan).

\section{Annexin V-FITC staining of apoptotic cells}

Apoptotic cells were quantified with the Annexin V-FITC Apoptosis detection kit according to the manufacturer's instructions (Roche). The cells were analysed with a Coulter Epics Altra flow cytometer (Koopman et al. 1994, Rizk-Rabin et al. 2008).

\section{PKA assay}

The PepTag non-radioactive protein kinase assay kit (Promega) was used to measure PKA activity according to the manufacturer's instructions. The reaction buffer (supplied with the PepTag kit) contained $1 \mu \mathrm{M}$ cAMP to ensure PKA activation. Bovine PKA (Promega) was used as a control for kinase activity, and PKA inhibitor (PKI; Sigma) was used as a specific PKI. The PepTag A1 peptide substrate was subjected to electrophoresis for $20 \mathrm{~min}$ in $1 \%(\mathrm{w} / \mathrm{v})$ agarose gels, and the separated bands were photographed with a phosphorimager. The intensities of the bands were analysed with Gene Tool software (Rizk-Rabin et al. 2008).

\section{Transfection and electroporation of the cells}

H295R cells were electroporated with AMAXA Nucleofector II (program T20 for H295R and program T30 for ATC1; Amaxa Biosystems, Cologne, Germany). 
HEK293 cells were transfected with the Lipofectamine 2000 protocol. We electroporated 5 million H295R cells (100 $\mu \mathrm{l}$ of AMAXA electroporation buffer, kit R) with $4 \mu \mathrm{l}$ of $80 \mathrm{pmol} / \mu \mathrm{l}$ of each siRNA (program T20). The siRNA used for targeting PRKARIIB was AUGUGAUGGUGUUGGAAGAdTdT(siR2b), and the siRNA control was CAGUCGCGUUUGCGACUGGdTdT (siS; Dharmacon, Chicago, IL, USA). Cells were used to seed 12-well plates, in which they were cultured for $24 \mathrm{~h}$. They were then cultured for $48 \mathrm{~h}$ in the presence or absence of $5 \mathrm{ng} / \mathrm{ml}$ tumour necrosis factor $\alpha(\mathrm{TNF} \alpha)$ or $25 \mathrm{ng} / \mathrm{ml} \mathrm{TGF} \beta$ (Sigma).

\section{Statistical analyses}

Data were analysed by ANOVA and regression analysis with Fisher's projected least significant difference or Scheffe's $F$ test for the comparison of means (StatView
5.0, SAS Institute, Cary, NC, USA). Data are expressed as means \pm s.E.M. Values of $P<0.05$ were considered significant. The number of experiments is defined in each figure legend.

\section{Results}

\section{$8 \mathrm{Cl}$-cAMP regulates the level of PKA subunits and increases basal PKA activity}

The PKA regulatory and catalytic subunits were affected differently by cAMP analogues (Fig. 1A). The results are expressed as fold inductions with respect to controls (the values for which were arbitrarily set to 1; Fig. 1B). Incubation with $8 \mathrm{Cl}$-cAMP decreased the $\mathrm{R} 1 \mathrm{~A}$ /actin ratio $(P<0.001$ on day 4 and $P=0.01$ on day 7$)$ and significantly increased the abundance of R2B on day 4 $(P=0 \cdot 004)$ and day $7(P=0 \cdot 003)$, as reported for other tumour cells (Kim et al. 2000, 2001). R2A levels were
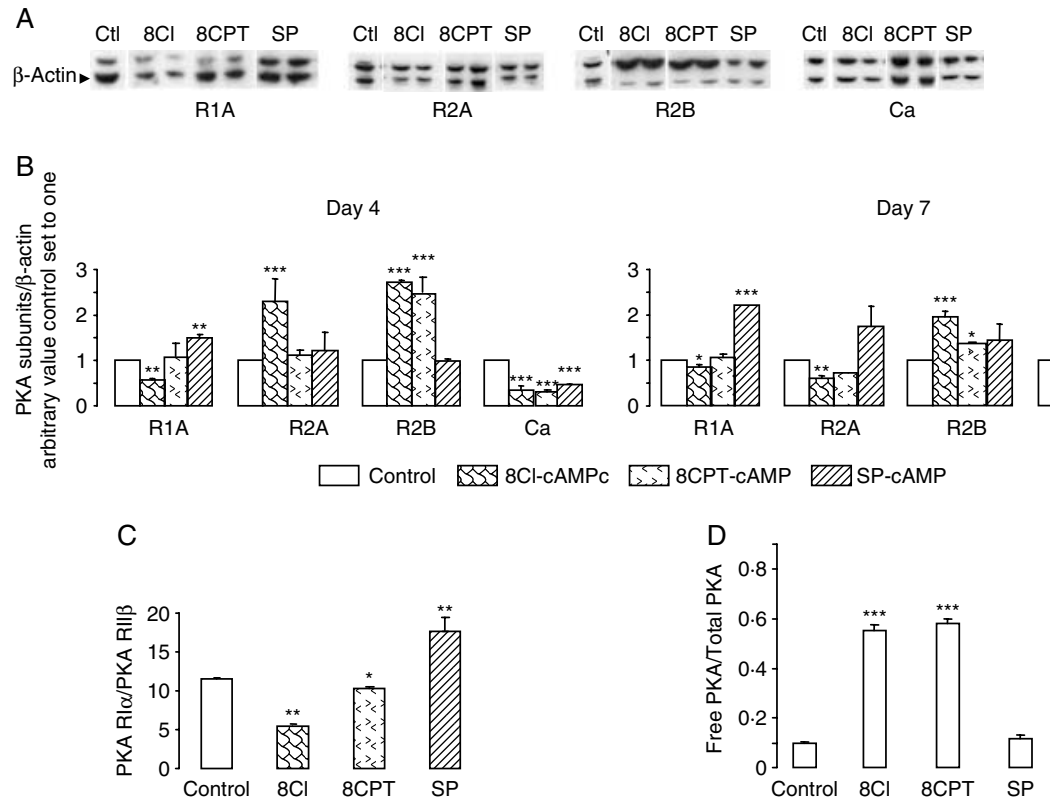

Figure 1 Effects of $8 \mathrm{Cl}$-cAMP on PKA regulatory subunits and PKA activity. (A) Western blots of the PKA subunits in cells treated with cAMP analogues (7 days). (B) The results are expressed as percentage relative band density/ $\beta$-actin of PKA subunits, normalised with respect to the corresponding controls (arbitrarily set to 1) in H295R treated cells. The results are the means \pm S.E.M. of three duplicate independent experiments. Day 4 analogue-treated cells compared with control arbitrarily set to 1 (for 8 -Cl-cAMP: R1A ${ }^{* \star} P=0.01, \mathrm{R} 2 \mathrm{~A}$ ${ }^{* * *} P=0.008, \mathrm{R} 2 \mathrm{~B}{ }^{* \star *} P=0.004$, Ca ${ }^{* \star *} P=0.0005$; for 8CPT-cAMP: R2B ${ }^{* \star *} P=0.0001$, Ca ${ }^{* \star} P=0.0005$; for SP-cAMP: R1A $\left.{ }^{* \star} P=0.02, \mathrm{Ca}{ }^{* \star *} P=0.0009\right)$. Day 7 analogue-treated cells compared with control (for $8 \mathrm{Cl}$-cAMP: R1A ${ }^{\star} P=0.02$, R2A ${ }^{\star \star} P=0.01, \mathrm{R} 2 \mathrm{~B}$ ${ }^{* *} P=0.003, \mathrm{Ca}{ }^{* * *} P<0.0001$; for $8 \mathrm{CPT}$-cAMP: R2B ${ }^{*} P=0.05, \mathrm{Ca}{ }^{* \star} P=0.001$; for SP-cAMP: R1A $\left.{ }^{\star \star \star} P<0 \cdot 0001, \mathrm{Ca}{ }^{\star *} P=0 \cdot 001\right)$. (C) PKA type 1/type 2 ratio. The results are the means \pm S.E.M. of three duplicate independent experiments, ${ }^{\star} P<0.05$ and ${ }^{* *} P<0.001$. (D) PKA activity. Cells cultured for $48 \mathrm{~h}$ were incubated with $100 \mu 8 \mathrm{Cl}$-cAMP, 8CPT-cAMP, SP-cAMP or vehicle for $15 \mathrm{~min}$. Cell extracts were prepared with (not shown) or without cAMP. The free PKA/total PKA ratio showed that cells exposed to $8 \mathrm{Cl}$-cAMP and 8 CPT-CAMP and extracted without CAMP had a higher PKA activity. The results are the means \pm S.E.M. of three duplicate independent experiments, and ${ }^{\star \star *} P<0.0001$. 
increased by 8Cl-cAMP only on day $4 \quad(P=0 \cdot 008)$. Incubation with 8CPT-cAMP had no effect on $\mathrm{R} 1 \mathrm{~A} /$ actin and $\mathrm{R} 2 \mathrm{~A} /$ actin ratios, but it strongly increased the $\mathrm{R} 2 \mathrm{~B} /$ actin ratio $(P<0 \cdot 0001$ on day 4 and $P<0.05 \%$ on day 7$)$. Similarly, incubation with SP-cAMP only increased R1A expression on day 7 $(P<0 \cdot 0001)$, but the $\mathrm{R} 2 \mathrm{~B} /$ actin and $\mathrm{R} 2 \mathrm{~A} /$ actin ratios remained unchanged. Significant accumulation of the Ca catalytic subunit was observed on day 7 with all cAMP treatments. The ratio of R1A PKA to R2B PKA subtypes was also significantly lower in 8Cl-cAMP-treated and 8CPT-cAMP-treated cells than in controls or SP-cAMPtreated cells (Fig. 1C).

Cells were incubated with the cAMP analogues for 15 min to determine whether the molecules had a direct effect on PKA activity. Basal PKA activity depended on the cAMP analogue. Cells incubated with 8Cl-cAMP had significantly higher levels of basal PKA activity corresponding to free PKA on total PKA ratio (measured in the absence of cAMP) than controls $(P<0 \cdot 0001$; Fig. 1D). The PKA activity of 8Cl-cAMP-treated cells measured in the presence of cAMP (representing the total PKA activity) was significantly higher than basal levels of PKA activity $(P<0 \cdot 05$; data not shown $)$. Similarly, 8CPTcAMP increased basal PKA activity in the absence of cAMP $(P<0 \cdot 001)$. SP-cAMP stimulation did not increase basal PKA activity to levels higher than those in control cell extracts. However, SP-cAMP-treated cells displayed higher levels of PKA activity than cAMP-treated control cells when assayed in the presence of cAMP $(P<0.05$; data not shown). PKA activity was completely abolished by the specific PKI (data not shown).

\section{$8 \mathrm{Cl}$-cAMP regulates cell viability and DNA synthesis}

The rate of cell viability was assessed by MTT assay in unsynchronised H295R cells. Population doubling times were long, and occurred at $>96 \mathrm{~h}$ (4 days; data not shown) as also reported by Gazdar et al. (1990) and Rainey et al. (1994). Cell viability was assessed on days 1 , 2, 4 and 7 (Fig. 2A and B). 8Cl-cAMP as the other cAMP analogues had no cytotoxic effects on H295R cells. Treatment with the different analogues did not affect cell viability on days 1 and 2 compared with untreated cells. On days 4 and 7 , a slight but statistically significant increase in cell viability was observed in 8Cl-cAMP-, 8CPT-cAMP- and SP-cAMP-treated cells $(P<0 \cdot 02$ and $P<0 \cdot 05$ versus control; Fig. 2A). The cell viability increase represented $1 \cdot 4$ - to $1 \cdot 5$-fold increase for 8CL-cAMP respectively on days 4 and 7 , and $1 \cdot 3$-fold induction for 8CPT-cAMP and SP-cAMP respectively on days 4 and 7 with respect to the corresponding control arbitrarily set to 1 (Fig. 2B). No significant differences in cell viability between treated groups were observed at any time point (Fig. 2A and B).
To assess whether 8Cl-cAMP modulates cell viability/proliferation, we evaluated DNA synthesis by H295R cells by monitoring BrdU incorporation for $6 \mathrm{~h}$ on days 2, 4, 6, and 7 after treatment with cAMP analogues (Fig. 2C). The study of BrdU incorporation along the kinetic time on days 2, 4, 6 and 7 showed that the level of replicating DNA (expressed as a \% BrdU staining) in 8Cl-cAMP-treated cells was significantly higher than that of replicating DNA in untreated control cells on days 2, 4 and $6(P<0.003$ for days 2 and 4 and $P=0.05$ for day 6 ). Similar results were obtained for $8 \mathrm{CPT}$ cAMP, while DNA synthesis in SP-cAMP-treated cells had the same level as the untreated cells (Fig. 2C). BrdU incorporation allows analysis of the pattern of the DNA synthesis along the time course in each group. DNA synthesis started to decrease on day 4 $(P=0.03$ versus day 2$)$ and day $7(P=0.01$ versus day $6)$ in both untreated cells and SP-cAMP-treated cells. The decrease in DNA synthesis occurred later on day 7 in 8Cl-cAMP-treated cells as in 8CPT-cAMPtreated cells $(P=0 \cdot 001$ and $P=0 \cdot 012$ respectively versus day 6$)$.

\section{Cl-cAMP treatment leads to the accumulation of cells in the $S$ and $G_{2}$ phases and enhances PCNA staining}

As the high level of DNA synthesis by $8 \mathrm{Cl}$-cAMP-treated cells was not reflected by the high proliferative rate in H295R cells, we analysed whether this mirrored a disturbance in cell cycle progression (Fig. 3A). Cells incubated with 8Cl-cAMP for 4 days were significantly fewer in the $\mathrm{G}_{0} / \mathrm{G}_{1}$ phase than controls $(57.7$ vs $66.7 \%$, $P<0.001)$ and more in the $\mathrm{S}$ phase $(24.5$ vs $15.5 \%$, $P<0.001$; Fig. $3 \mathrm{~A}$ and $\mathrm{B})$. The accumulation of cells in the $\mathrm{S}$ and $\mathrm{G}_{2}$ phases continued until day 7 (24 vs $19 \%$, $P<0.05$ for the $\mathrm{G}_{2}$ phase; Fig. 3B). The same decrease in the number of $\mathrm{G}_{0} / \mathrm{G}_{1}$ cells was observed 7 days after 8CPT-cAMP treatment $(51.84$ vs $63.1 \%, P<0 \cdot 001)$, with an accumulation mostly in the $\mathrm{S}$ and $\mathrm{G}_{2}$ phases being observed on day 7 (24.8 vs $19 \%, P<0.05$ for the $G_{2}$ phase; Fig. $3 \mathrm{~A}$ and $\mathrm{B}$ ). About $66.7 \%$ of untreated H295R cells (controls) were in the $\mathrm{G}_{0} / \mathrm{G}_{1}$ phase, $15 \cdot 5 \%$ were in the $S$ phase and $18.3 \%$ were in the $G_{2} / M$ phase (Fig. 3A and B). The SP-cAMP-treated cells displayed a similar distribution between the phases of the cell cycle as control cells.

We used a PCNA-PE antibody to assess the accumulation of cells in the S phase by flow cytometry (Beppu et al. 1994; Fig. 3C). The 8Cl-cAMP-treated cells displayed significantly higher levels of PCNA-PE staining $(23.05 \%, P<0.001)$ than controls after day 7 . The observed levels of PCNA staining were also higher in 8CPT-cAMP-treated cells $(16.3 \%, P<0 \cdot 05)$. The percentage of SP-cAMP-treated cells in the $\mathrm{S}$ phase was $1 \cdot 24 \%$. 
A
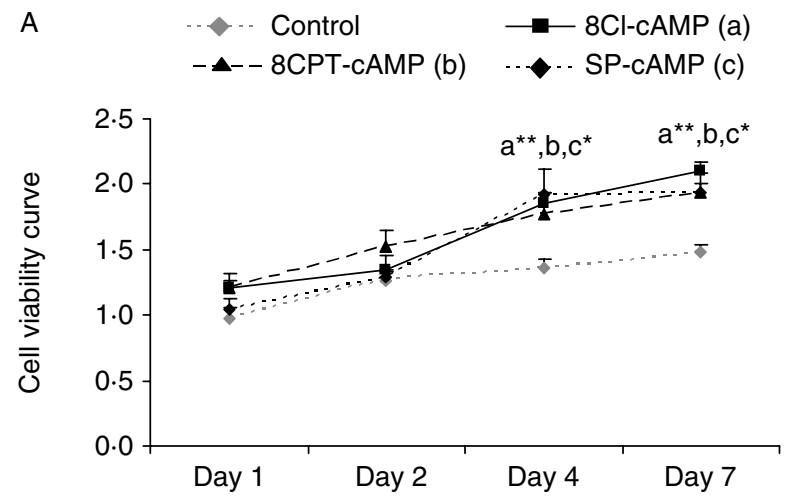

C
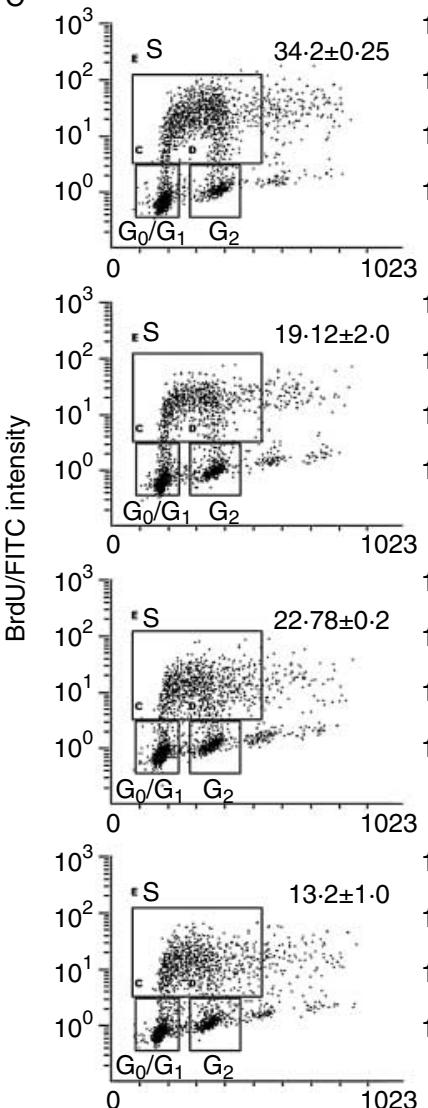

8Cl-cAMP
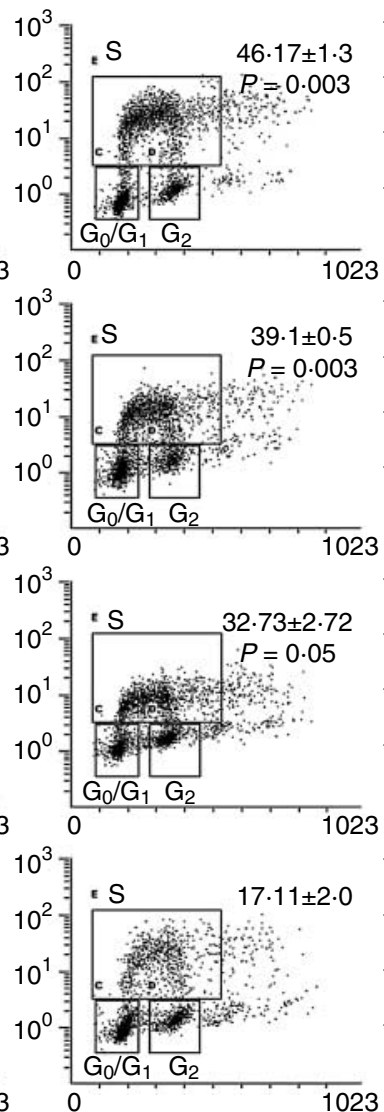

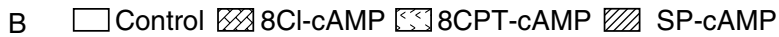

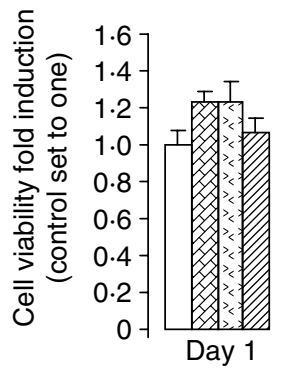

8CPT-CAMP
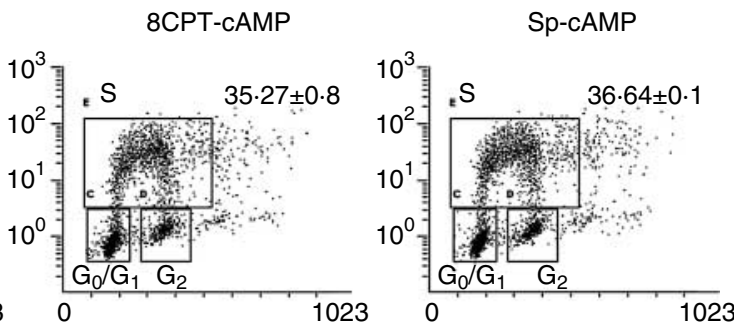

Day 2
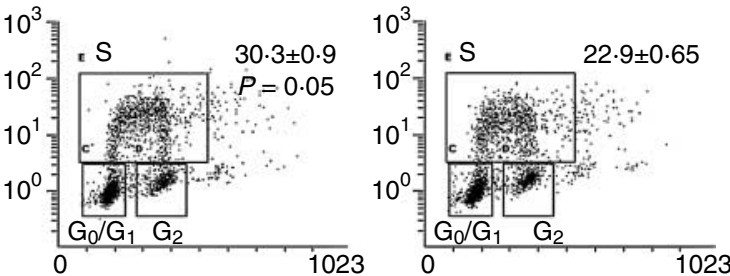

Day 4
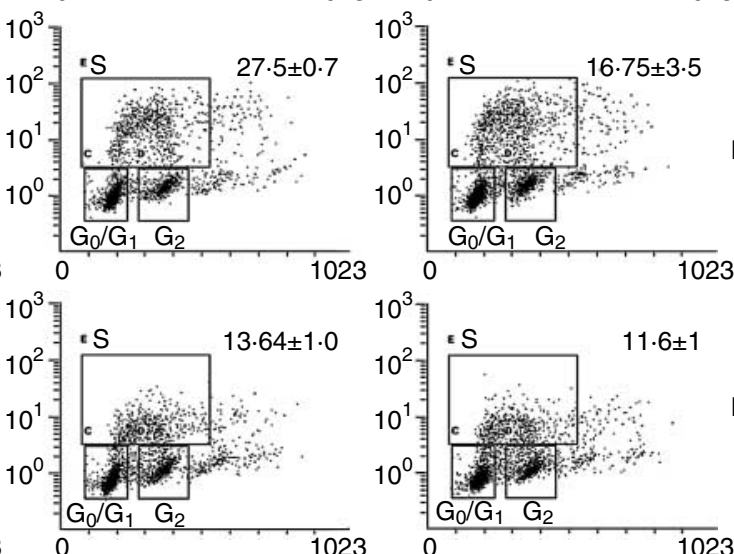

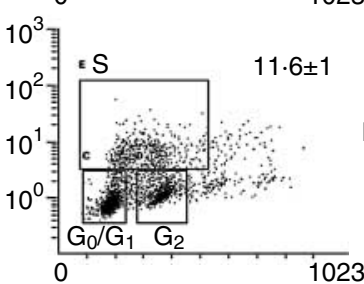

Figure 2 Effects of $8 \mathrm{Cl}$-cAMP on cell survival and DNA synthesis. (A) Cell survival curve of $\mathrm{H} 295 \mathrm{R}$ cells, as assessed by the MTT assay in

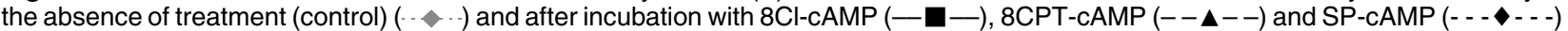
for 1, 2, 4 or 7 days. Cells were plated $48 \mathrm{~h}$ before treatment. (B) Cell survival, and fold induction on control set to 1 . Each MTT assay was performed in quintuplicate. In (A), the results are the means + S.E.M. of one MTT experiment among three MTT independent experiments: b, ${ }^{*} P<0.05$ for 8 CPT-cAMP and SP-cAMP respectively; a ${ }^{* *} P<0.02$ for $8 \mathrm{Cl}$-cAMP versus untreated control. In (B), the results of fold induction with respect to the corresponding control set to 1 are the means \pm s.E.M. of three MTT independent experiments: ${ }^{*} P=0 \cdot 05$, ${ }^{* \star} P=0.02$ and ${ }^{\star \star *} P=0.005$ versus control (untreated cells). (C) BrdU incorporation reflects the newly replicated DNA (S phase) during the time of $\mathrm{BrdU}$ incorporations. Cells were labelled with $\mathrm{BrdU}$ for $6 \mathrm{~h}$ at the end of each incubation period $(2,4,6$ and 7 days). BrdU incorporation was analysed after incubation with BrdU FITC antibody and propidium iodide. The upper square shows the percentage BrdU incorporation during the $S$ phase. The results are the means \pm S.E.M. of three duplicate independent experiments. ${ }^{*} P<0.05$ and ${ }^{*} P=0.003$ versus untreated cells for the corresponding day. 

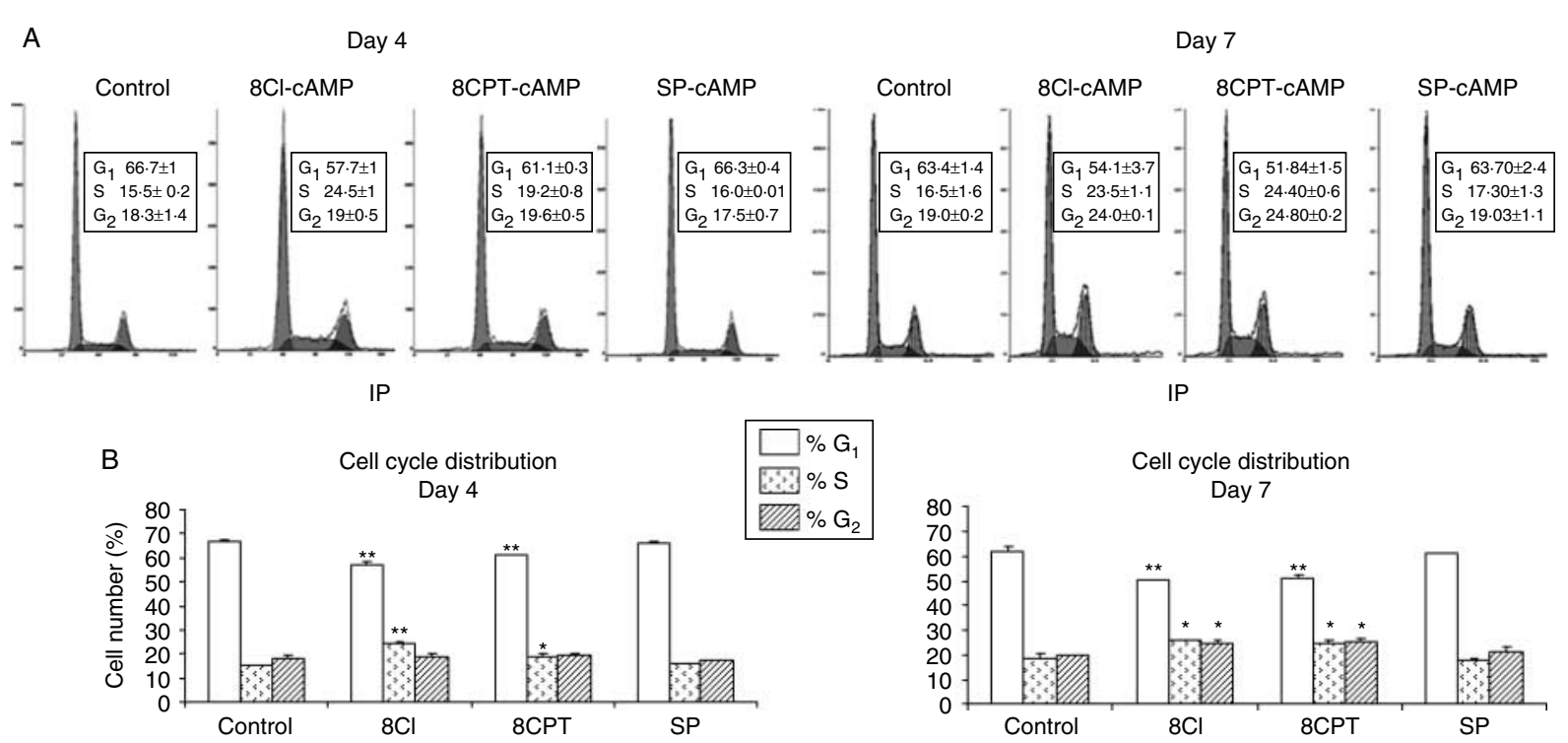

C
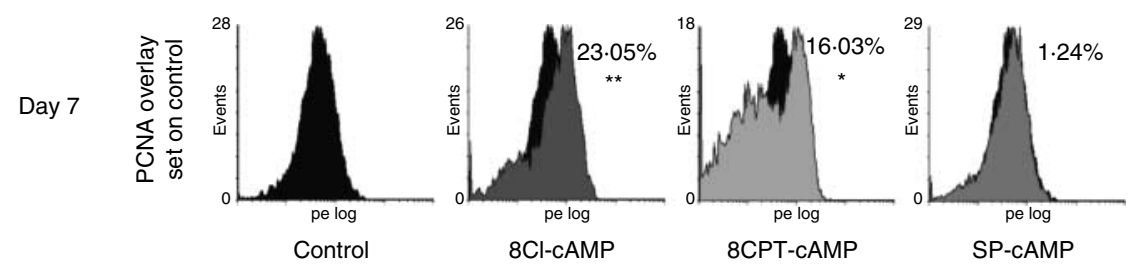

Figure 3 Effects of $8 \mathrm{Cl}$-cAMP on cell cycle distribution and PCNA. (A) The distribution of cells in the various phases of the cell cycle was analysed by propidium iodide incorporation after stimulation for 4 and 7 days with $8 \mathrm{Cl}$-cAMP, $8 \mathrm{CPT}$-cAMP or SP-cAMP (100 $\mu$ M). (B) The cell cycle distribution is plotted as a histogram. $8 \mathrm{Cl}$-cAMP induced the accumulation of cells in the $\mathrm{S}$ and $\mathrm{G}_{2}$ phases, and decreased the percentage of cells in the $G_{0} / G_{1}$ phase. (C) The accumulation of cells in the $S$ phase was assessed by PCNA staining and FACS flow cytometry. The results presented are an overlay of the PCNA staining of treated and untreated cells (controls). Observations depicted in $(A)$ and $(C)$ are from the same experiment. The percentage indicated is the mean \pm S.E.M. of three duplicate independent experiments. ${ }^{\star} P<0.05$ and ${ }^{\star \star} P<0.001$ versus control.

\section{Cl-cAMP causes the accumulation of cyclin $\mathrm{B}$ in the cytosol and the nucleus and modulates CDK2 and CDC2 kinase activities}

The accumulation of cells in the $\mathrm{S}$ and $\mathrm{G}_{2}$ phases may result from the deregulation of cell cycle regulatory proteins, disturbing the checkpoint transition. We analysed the concentrations of cyclin E, cyclin A and cyclin B in the cell cytosol and nuclear fractions by western blotting on day 4 (Fig. 4). All cAMP analogues decreased cyclin $\mathrm{E}$ concentration in the cytosolic extracts and increased cyclin $\mathrm{E}$ concentration in the nuclear extracts, reflecting the transition from the $G_{1}$ phase to the S phase. Similarly, cyclin A concentration was higher in the nucleus. The nuclear translocation of cyclin $\mathrm{A}$ is an indicator of the $\mathrm{S}$ phase. By contrast, only cells incubated with 8Cl-cAMP displayed a significant increase $(P<0 \cdot 001)$ in cyclin $\mathrm{B}$ levels in cytosolic and nuclear extracts (Fig. 4A and B), reflecting abnormal cell cycle progression through mitosis. Cells incubated with 8CPT-cAMP also accumulated cyclin B, but only in the nuclear fraction, again reflecting abnormal $\mathrm{G}_{2} / \mathrm{M}$ cell cycle progression.

Cyclins are active in complexes with cyclin-dependent kinases, and the consecutive activation of cyclin-cdk complexes is required for progression through critical checkpoints within the cell cycle. We assessed the kinase activities associated with immunoprecipitated CDK2 (responsible for S phase entry) and CDC2 (responsible for entry into and exit from mitosis) in cells incubated with the various cAMP analogues (Fig. 4C). The CDK2 and CDC2 immunocomplexes were labelled with the antibodies against CDK2 and CDC2 respectively (Fig. 4C $\mathrm{Wb})$. The apparent molecular weight of the immunoprecipitated CDK2 and CDC2 proteins $(33 \mathrm{kDa})$ on Coomassie blue-stained SDS-PAGE gels (Fig. 4C) was as expected. The amounts of immunoprecipitated CDK2 and CDC2 were similar in all treated and control cells (Fig. 4C Comassie blue), but differences were observed in the corresponding kinase activities (Fig. 4C histone kinase). Levels of CDK2 kinase activity were higher in cells treated with 8Cl-cAMP, which had lower levels of 
A

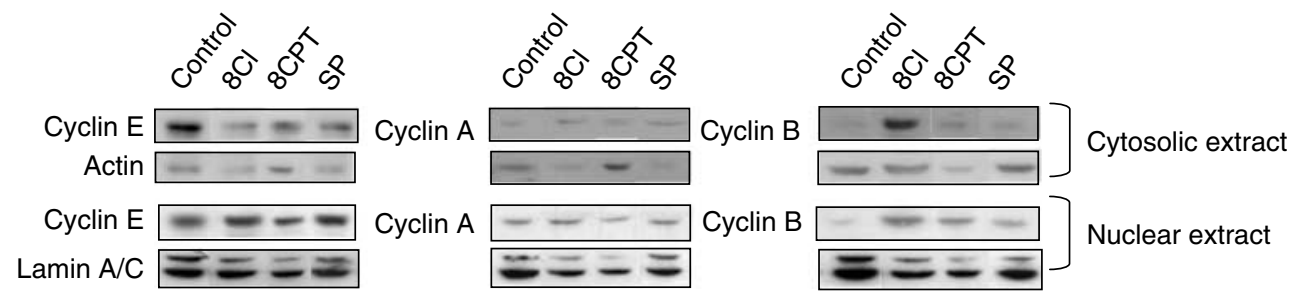

B

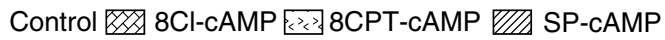

${ }^{*} P<0.02$

Cytosolic extract
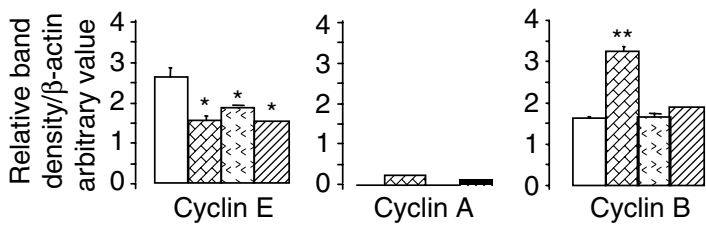

Nuclear extract
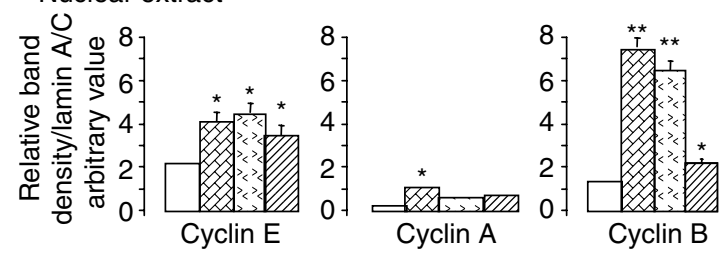

C

IP CDK2
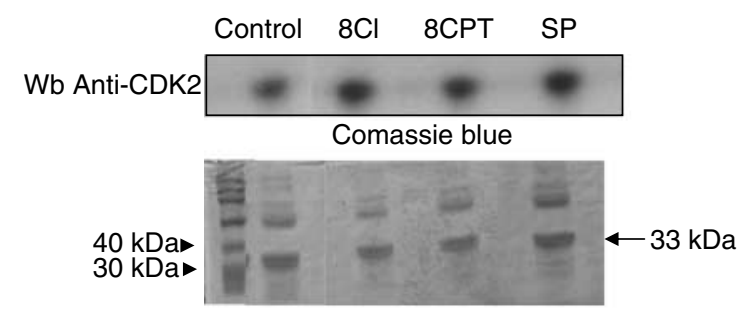

$\gamma$ ATP $P^{32}$

$\gamma$ Histone kinase assay

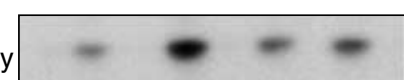

IP CDC2

Control 8Cl 8CPT SP
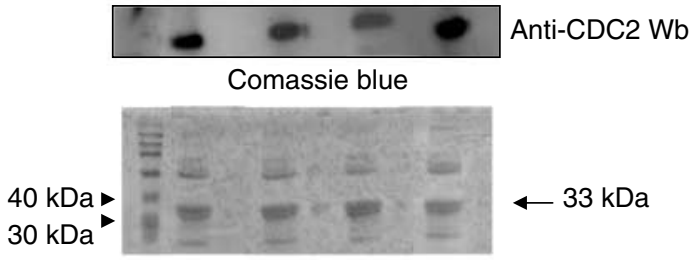

$\gamma$ ATP $\mathrm{P}^{32}$

$\gamma$ Histone kinase assay

Figure 4 Effects of $8 \mathrm{Cl}$-cAMP on the cyclin contents of cytosolic and nuclear extracts and on the cyclin-dependent kinases, CDK2 and CDC2. (A) Western immunoblot analysis of cyclin $E\left(G_{1}\right)$, cyclin $A(S)$ and cyclin $B\left(G_{2}\right)$ in the cytosolic and nuclear extracts after 4 days of treatment. (B) Relative band density (cyclin/ $\beta$-actin) of the cyclins in cytosolic extracts, and relative band density (cyclin/lamin $\mathrm{A} / \mathrm{C}$ ) in nuclear extract. The results are the mean \pm S.E.M. of three duplicate independent experiments, ${ }^{*} P<0.05$ and ${ }^{\star *} P<0.001$.

(C) Western blot $(\mathrm{Wb})$ of immunoprecipitated CDK2 or CDC2 with anti-CDK2 and anti-CDC2 respectively. Immunoprecipitation (Coomassie blue) of CDK2 and CDC2 proteins from cells incubated with cAMP analogues for 4 days. Autoradiography of CDK2- and CDC2-associated histone kinase activities assessed in immunoprecipitated CDK2 or CDC2 using histone H1 as a substrate. This is one of the representations. The relative activity of CDC2 and CDK2 blots is based on the measurement of the density of kinase band normalised to the density of the corresponding band of the loading immunoprecipitated protein complex visualised by Coomassie blue. The ratio of CDK2 activity for each treatment compared with control (set to 1 ) is $8 \mathrm{Cl} 3.16 \pm 0 \cdot 16, P<0.0001 ; 8 \mathrm{CPT} 1.53 \pm 0.048$, $P=0.004$; SP-cAMP 1.64 $\pm 0.17, P=0.001$; and for CDC2 kinase activity: $8 \mathrm{Cl} 0.732 \pm 0.01, P<0.0001 ; 8 \mathrm{CPT} 0.865 \pm 0.012$, $P=0.002$; SP-cAMP $1.845 \pm 0.05, P<0.0001$.

CDC2 kinase activity. Cells incubated with 8CPT-cAMP displayed levels of CDK2 kinase activity higher than those displayed by the control cells, but lower than those displayed by the cells incubated with 8Cl-cAMP. Levels of CDC2 kinase activity were lower in 8CPT-cAMP cells than in control cells. By contrast, cells incubated with SP-cAMP displayed higher levels of CDK2 and CDC2 kinase activities than control cells. However, CDK2 kinase activity levels were lower in SP-cAMP-treated cells than in cells incubated with 8Cl-cAMP (Fig. 4C), whereas SP-cAMP-treated cells had higher levels of CDC2 kinase activity than cells incubated with 8Cl-cAMPor 8CPT-cAMP (Fig. 4C).

\section{Cl-cAMP affects cell cycle progression}

Two molecules were used to synchronise the cells aphidicolin for the $\mathrm{S}$ phase and nocodazole for the $\mathrm{G}_{2} / \mathrm{M}$ phase - to identify the checkpoint transition affected by 8Cl-cAMP (Uzbekov 2004). Cells were incubated with aphidicolin for $24 \mathrm{~h}$, or with nocodazole for $48 \mathrm{~h}$. They were then placed in a medium without aphidicolin or nocodazole, and incubated with the cAMP analogue or medium alone. The distribution of cells in the various phases of the cell cycle was analysed at $6,12,24$ and $48 \mathrm{~h}$. Incubation with aphidicolin for $24 \mathrm{~h}$ caused cells to accumulate in the late $\mathrm{G}_{1} / \mathrm{S}$ phase, 
at the $\mathrm{G}_{1} / \mathrm{S}$ border $\left(72 \%\right.$ in the late $\mathrm{G}_{1}$ phase; Fig. $\left.5 \mathrm{~A}\right)$. Most (64\%) of the cells that were returned to medium alone were in the $S$ phase at $6 \mathrm{~h}$, progressed to the $\mathrm{G}_{2}$ phase by $12 \mathrm{~h}$, and divided and showed a normal cell cycle distribution $24 \mathrm{~h}$ after release (Fig. 5B). At $12 \mathrm{~h}$, entry into the $\mathrm{G}_{2}$ phase was delayed for cells incubated with $8 \mathrm{Cl}$-cAMP. More number of these cells $(65 \%)$ were still in the $\mathrm{S}$ phase compared with those placed in the normal medium $(47 \%, P<0 \cdot 001$; Fig. 5B). However, fewer 8Cl-cAMP-treated cells $(7 \%)$ were present in the $\mathrm{G}_{2}$ phase than control cells $(30 \%, P<0 \cdot 002)$. The $8 \mathrm{Cl}$-cAMP-treated cells then progressed through the cell cycle at 24 and $48 \mathrm{~h}$, as did those placed in the normal medium. However, a significantly smaller

A Normal medium+Aphidicolin B Time release

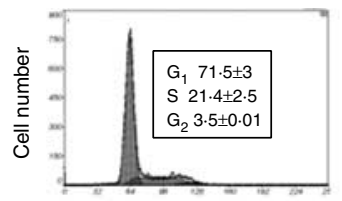

DNA content
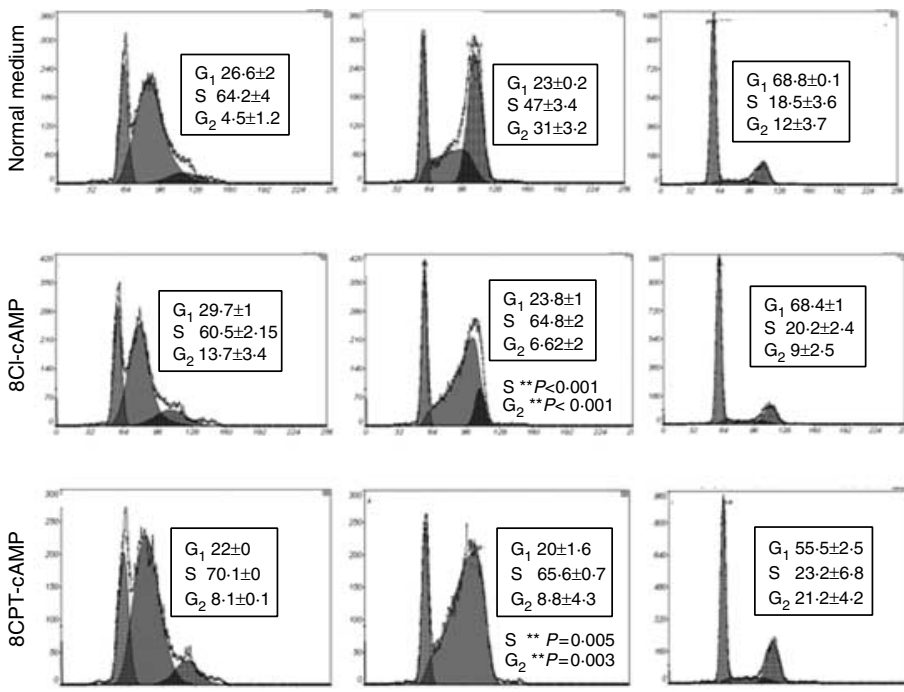

$6 \mathrm{~h}$

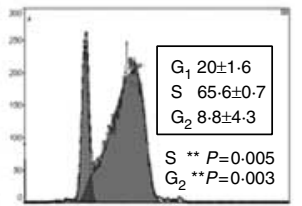

$12 \mathrm{~h}$
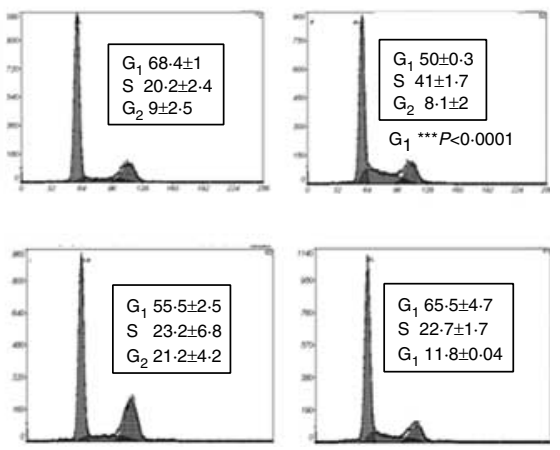

$24 \mathrm{~h}$

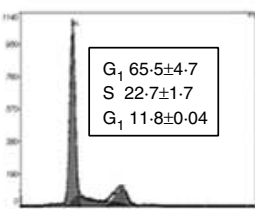

$48 \mathrm{~h}$

\section{Normal medium+Nocodazole D Time release}

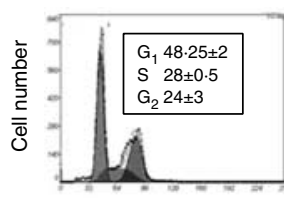

DNA content
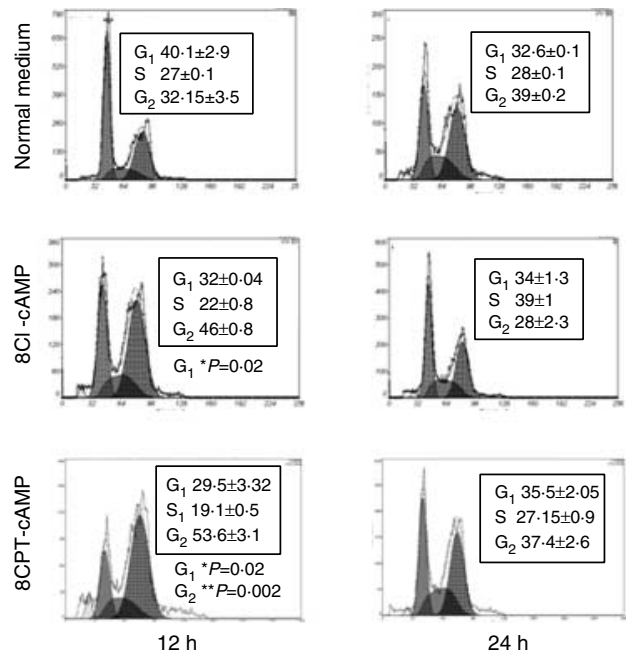

$24 \mathrm{~h}$
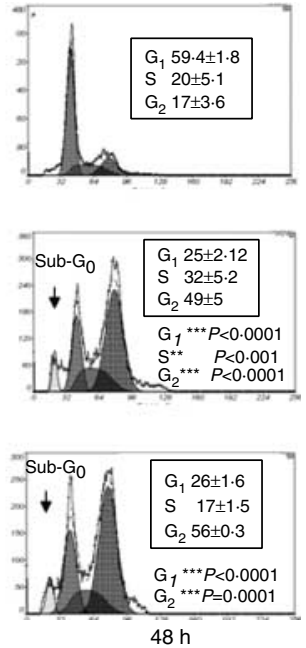

Figure 5 Effects of $8 \mathrm{Cl}$-cAMP on cell cycle progression in cells treated with aphidicolin or nocodazole. (A) Cell cycle distribution after incubation with aphidicolin for $24 \mathrm{~h}$. (B) Cell cycle distribution of cells incubated in the normal medium, 8Cl-cAMP and 8CPT-cAMP for 6 , 12,24 and $48 \mathrm{~h}$ after the removal of aphidicolin. (C) Cell cycle distribution after incubation with nocodazole for $48 \mathrm{~h}$. (D) Cell cycle distribution of cells incubated in the normal medium, 8Cl-cAMP and 8CPT-cAMP for 6, 12, 24 and $48 \mathrm{~h}$ after the removal of nocodazole. The representative cell cycle profile was obtained in one experiment and the percentages of cells in cell cycle phases are the means \pm S.E.M. of three duplicate independent experiments. ${ }^{\star} P<0.02,{ }^{\star \star} P<0.001$ and ${ }^{\star * \star} P<0.0001$ in comparison with the control at the indicated phase. 
percentage of the treated cells were in the $\mathrm{G}_{0} / \mathrm{G}_{1}$ phase at $48 \mathrm{~h}(P<0 \cdot 0001$ versus normal medium; Fig. 5B). As for 8Cl-cAMP, treatment with 8CPT-cAMP also delayed entry into the $\mathrm{G}_{2}$ phase. At $12 \mathrm{~h}$, the percentage of cells in the $S$ phase was 65.6 vs $47 \%$ of those placed in the medium alone $(P=0 \cdot 005)$, and that of cells in the $\mathrm{G}_{2}$ phase was 8.8 vs $31 \%$ of those placed in the medium alone (Fig. 5B).

Incubation with nocodazole for $18 \mathrm{~h}$ is effective in many types of cells, resulting in an accumulation of cells in the $\mathrm{G}_{2} / \mathrm{M}$ phase (Uzbekov 2004), but H295R cells required incubation for $48 \mathrm{~h}$ to establish a partial $\mathrm{G}_{2} / \mathrm{M}$ blockade, with fewer cells in the $\mathrm{G}_{0} / \mathrm{G}_{1}$ phase $(48 \%$; Fig. 5C) than non-synchronised control cells $(66.7 \%$; Fig. 3A), and in the accumulation of cells in the $S$ phase $(28 \%)$ and the $\mathrm{G}_{2}$ phase (24\%; Fig. 5C). Cells treated with 8Cl-cAMP for $48 \mathrm{~h}$ (after nocodazole) did not divide or enter the normal cell cycle (Fig. 5D). Cells remained blocked in the $\mathrm{S}(32 \%)$ and $\mathrm{G}_{2}(49 \%)$ phases, with percentages of cells in these phases being well above those for controls placed in the medium alone (20\% in the $\mathrm{S}$ phase, $P<0.001$, and $17 \%$ in the $\mathrm{G}_{2}$ phase, $P<0.0001$; Fig. 5D). This resulted in a proportion of cells in the $\mathrm{G}_{1}$ phase $(25 \%)$ much smaller than the $59.5 \%$ in this phase in controls $(P<0 \cdot 0001)$. Cells incubated with 8CPT-cAMP accumulated in the $\mathrm{G}_{2}$ phase $12 \mathrm{~h}$ after release $(53 \cdot 6$ vs $32 \cdot 15 \%$ of those placed in the normal medium, $P=0 \cdot 002$ ), and were blocked in the $\mathrm{G}_{2}$ phase at $48 \mathrm{~h}$ (56\% in the $\mathrm{G}_{2}$ phase, $17 \%$ in the $\mathrm{S}$ phase and $26 \%$ in the $G_{1}$ phase versus 17,20 and $59 \cdot 42 \%$ respectively of those placed in the medium alone; Fig. 5D). The control cells gradually entered the normal cell cycle (Fig. 5D). Cells arrested in the $\mathrm{G}_{2}$ phase showed a small sub- $G_{0}$ peak, indicating the appearance of apoptotic cells after incubation with 8Cl-cAMP and 8CPT-cAMP for $48 \mathrm{~h}$ (Fig. 5D).

\section{Cl-cAMP induces apoptosis}

We studied the early apoptotic pathway by annexin $\mathrm{V}$ staining to confirm that treatment with 8Cl-cAMP and the accumulation of cells in the $\mathrm{S} / \mathrm{G}_{2} / \mathrm{M}$ phase enhanced apoptosis (Koopman et al. 1994). A higher proportion of cells treated with 8Cl-cAMP than of control cells entered apoptosis on day $4(* P<0 \cdot 05$, data not shown) and day $7(* * P<0 \cdot 001)$. The proportion of cells treated with TGF $\beta(25 \mathrm{ng} / \mathrm{ml})$ entering apoptosis was also higher $(* * P<0 \cdot 001$; Fig. $6 \mathrm{~A}$ and B). Significantly more number of the 8Cl-cAMP-treated cells than of the control cells were apoptotic (early, late

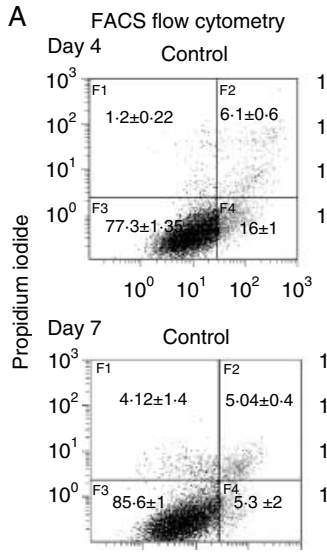

$\begin{array}{llll}10^{0} & 10^{1} & 10^{2} & 10^{3}\end{array}$
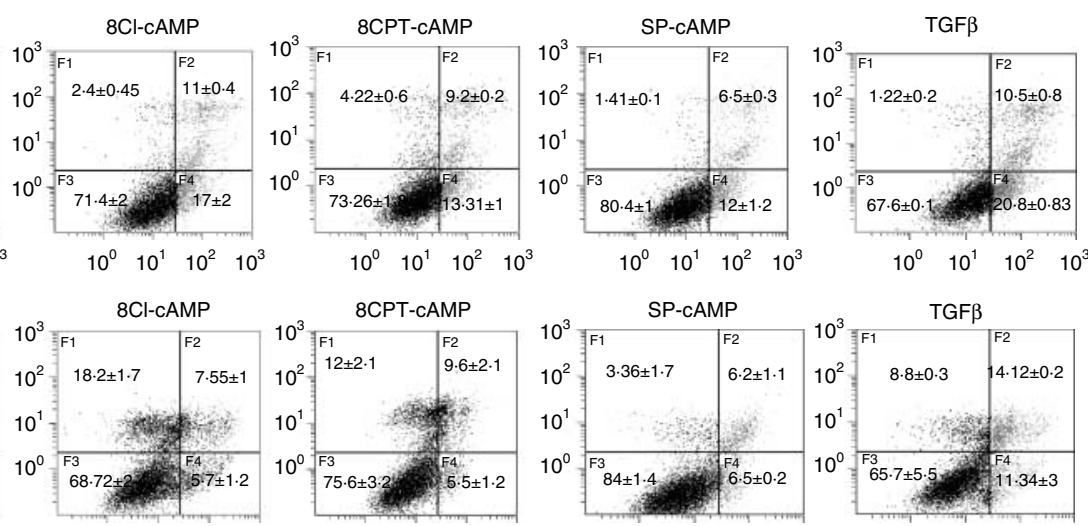

$\begin{array}{llll}10^{0} & 10^{1} & 10^{2} & 10^{3}\end{array}$ Annexin V FITC
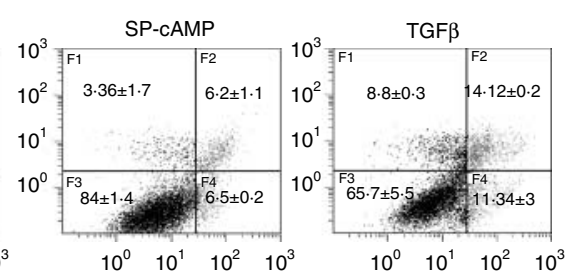

$\begin{array}{llll}10^{0} & 10^{1} & 10^{2} & 10^{3}\end{array}$

B

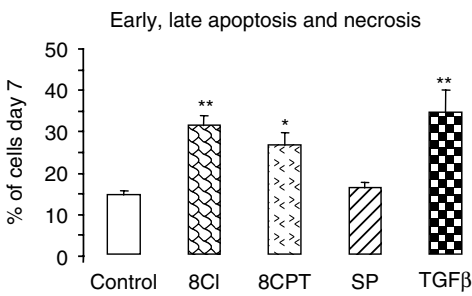

Figure 6 Effects of $8 \mathrm{Cl}$-cAMP on apoptosis. Apoptosis was assessed by annexin V-FITC/IP staining, and measured by FACS flow cytometry in cells incubated with $8 \mathrm{Cl}$-cAMP, $8 \mathrm{CPT}$-cAMP, SP-cAMP or TGF $\beta(25 \mathrm{ng} / \mathrm{ml})$ for 4 or 7 days. (A) A representative dot plot. Points are the means \pm S.E.M. of three duplicate experiments, expressed as percentage apoptosis. (B) Results are expressed as the percentage of cells undergoing apoptosis (early annexin ${ }^{+} / \mathrm{IP}^{-}$, late apoptosis annexin ${ }^{+} / \mathrm{IP}^{+}$and necrosis annexin ${ }^{-} / \mathrm{IP}^{+}$). $\mathrm{Points}$ are the means \pm S.E.M. of three triplicate independent experiments. ${ }^{*} P<0.02$ and ${ }^{* \star} P<0.001$. 
apoptosis and necrotic cells; $* * P<0 \cdot 001$; Fig. 6B). Similar results were obtained when cells were treated with 8 CPT-cAMP $\left({ }^{*} P<0 \cdot 02\right.$; Fig. $6 \mathrm{~A}$ and $\left.\mathrm{B}\right)$.

\section{$R 2 B$ invalidation enhances cell survival and reduces apoptosis}

We invalidated the $R 2 B$ gene to determine whether R2B was a key regulator of cell proliferation or apoptosis in H295R cells. Electroporation with an siRNA against R2B was carried out, and its efficacy was confirmed by the decrease in $R 2 B$ /actin ratio observed on western blots of H295R and HEK293 cells (Fig. 7A). As transient transfection methods allow only limit periods of time for studying H295R cell proliferation, we studied the effect of $R 2 B$ invalidation on the apoptosis induced by TGF $\beta$ and TNF $\alpha$ (Mikhaylova et al. 2007) over a maximum of $48 \mathrm{~h}$. Flow cytometry with annexin staining showed that siR2B-transformed cells were more in the annexin-IP cluster (viable cells) in basal conditions $(79.5$ vs $72 \%$ control, $P<0.05$; Fig. $7 \mathrm{~B}$ and $\mathrm{C}$ ). The invalidation of $R 2 B$ significantly decreased the percentage of apoptotic cells after $48 \mathrm{~h}$ of stimulation with TNF $\alpha$ and TGF $\beta$, as shown by comparison with treated siS control (Fig. 7B and C). This effect on cell survival was cell specific. Treatment with TGF $\beta$ and TNF $\alpha$ induced apoposis in siS control HEK293 cells (TGF $\beta 42 \cdot 47 \%$, TNF $\alpha 38 \cdot 6$ vs $21 \cdot 12 \%$ siS control, $* P=0.05$ and $* * P=0.02$ respectively) and in MCF-7 cells $(* * * P<0 \cdot 0001$; Stoika et al. 2008; Fig. 7C). Invalidation of $R 2 B$ in HEK293T and MCF-7 cells had no effect on apoptosis induced by TGF $\beta$ and $\mathrm{TNF} \alpha$ in siS as shown by comparison with treated siS control cells.

\section{Discussion}

Here, we have demonstrated that altering the balance between PKA R1A and PKA R2B influences cell growth in the human adrenocortical carcinoma cell line H295R. The main finding of the study is that activation of R2B and enhancement of its expression using two selective cAMP analogue activators for R2B dysregulate cell cycle progression and induce apoptosis. R2B plays an important role in H295R apoptosis, which is confirmed by silencing $R 2 B$ gene, since inactivation of R2B confers resistance to apoptosis.

8Cl-cAMP, a site-selective analogue for the type 2 PKA, may affect the growth of several types of cells through its extracellular conversion into a cytotoxic metabolite, 8Cl-adenosine (Lange-Carter et al. 1993, Robinson-White et al. 2008), or by influencing the ratio of PKA isozymes in the cell, thereby modifying PKA activity (Rohlff et al. 1993, Kim et al. 2001). In our study, the effects of 8Cl-cAMP on cell viability, DNA synthesis and apoptosis in H295R cells are not linked to its conversion to 8Cl-adenosine, because 8CPT-cAMP, a site-selective cAMP analogue specific for the type 2 PKA, which is not converted to 8Cl-adenosine, has similar effects. Moreover, using a synthetic Ultroser G serum rather than using foetal bovine serum may rule out the presence of enzymes catalysing the conversion to $8 \mathrm{Cl}$-adenosine.

We found that the inhibition of H295R cell growth is a late event, occurring after the onset of apoptosis. $8 \mathrm{Cl}$ cAMP has no cytotoxic effects on cells, and initially increases DNA-replicating cells and maintains the level high for over 6 days and then decreases DNA synthesis on day 7. However, the increase in DNA-replicating cells analysed by BrdU incorporation is not in concordance with the limited increase of $1 \cdot 5$-fold in cell viability on days 4 and 7 . While the same fold increase in cell viability $(1 \cdot 3$-fold $)$ is observed in SP-cAMP-treated cells, no sustained DNA synthesis occurs. Viability of 8Cl-cAMP- and 8CPT-cAMP-treated cells decreases after 10 days of incubation (data not shown). The discordance between DNA synthesis and the limited increase in cell viability is explained by the fact that not all DNA-replicating cells divide. This is shown by the analysis of DNA content after propidium iodide incorporation where the $S$ and $G_{2}$ phases increase and the $\mathrm{G}_{1}$ phase decreases. An accumulation of DNA content in the $S$ phase is observed on days 4 and 7 . The $S$ phase accumulation on day 7 , which is not observed using BrdU, is due to the incorporation of propidium iodide in all the DNA-replicating cells, which is not limited to the newly replicating cells in a range of $6 \mathrm{~h}$ as for BrdU incorporation. The high PCNA staining also reflects the accumulation of the cells in the $S$ phase. The accumulation in the $\mathrm{S}$ phase without induction of proliferation is also reported in primary mouse epidermal keratinocytes (Dransfield et al. 2001). 8Cl-cAMP-treated keratinocytes arrested in the $\mathrm{G}_{2} / \mathrm{M}$ phase can still incorporate ${ }^{3} \mathrm{H}$ thymidine, but cannot divide. 8Cl-cAMP as 8CPT-cAMP initially causes a transient stimulation of the cell cycle in H295R cells, which is followed by apoptosis and the inhibition of growth due to perturbation of the cell cycle.

Two phases of the cell cycle are mainly affected by the R2B site-selective cAMP analogues: first, the transition of the cells from the $S$ phase to the $G_{2}$ phase as demonstrated by the increase in the percentage of the $S$ phase cells, the intense PCNA staining, sustained DNA synthesis (BrdU incorporation) and the delayed entry into the $\mathrm{G}_{2}$ phase as shown by the aphidicolin synchronisation. Secondly, the transition from the $\mathrm{G}_{2}$ phase to mitosis; the cells accumulated in the $\mathrm{G}_{2}$ phase do not go on to divide. The prolonged arrest in the $\mathrm{G}_{2}$ phase, as shown by nocodazole synchronisation, leads to a decrease in the proportion of cells in the $G_{0} / G_{1}$ 
A
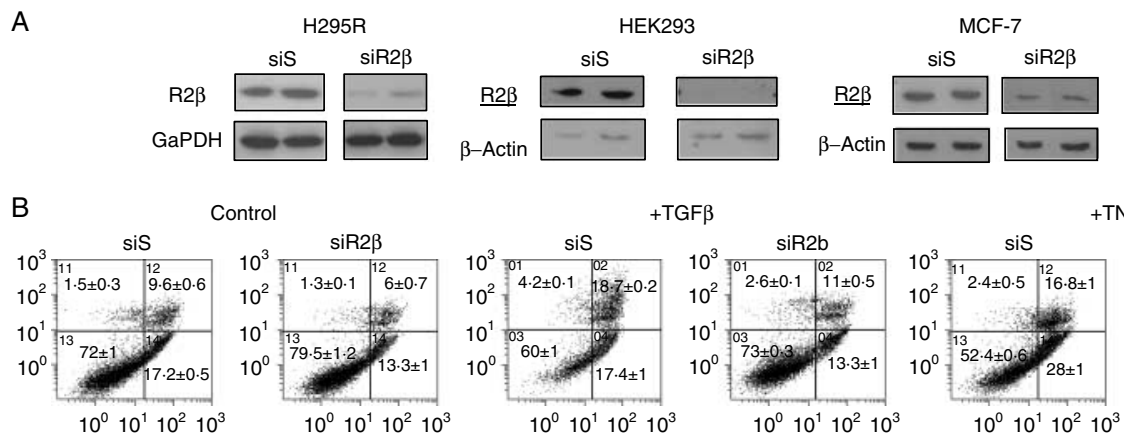

$+\mathrm{TNF} \alpha$

H295R

C

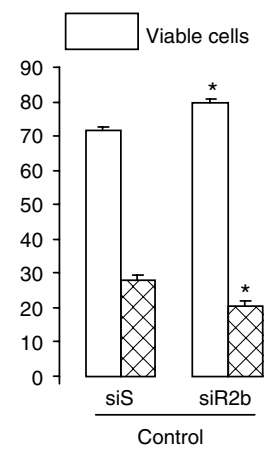

XX Apoptotic cells
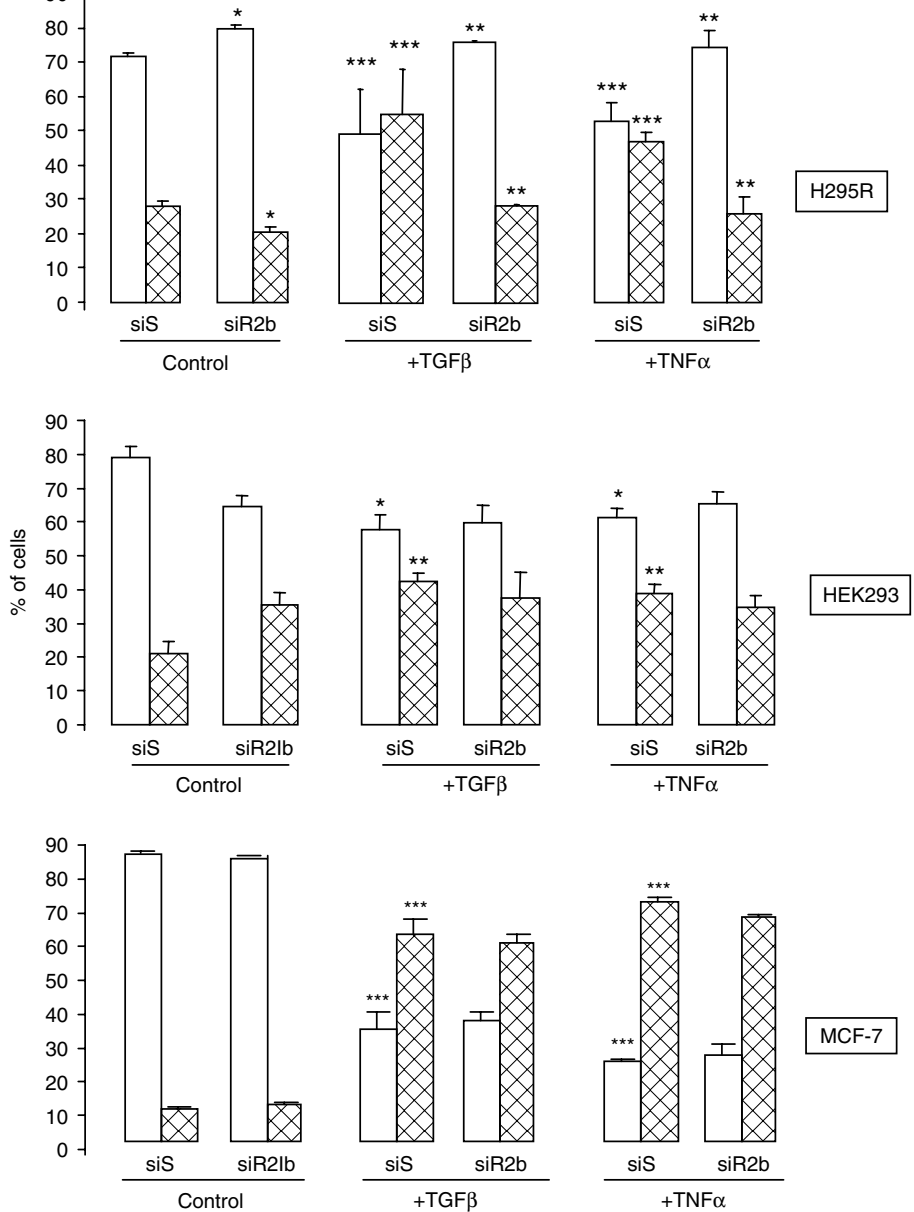

Figure 7 Effects of PKA R2B invalidation on cell survival and the apoptosis induced by TGF $\beta$ and TNF $\alpha$ in H295R, HEK293T and MCF-7 cell lines. Apoptosis was assessed by annexin V-FITC/IP staining, and measured by FACS flow cytometry in cells invalidated for PKA R2B by electroporation. Cells electroporated with scrambled siRNA (siS) or an siRNA against R2B (siR2B) were incubated for $48 \mathrm{~h}$ in the presence or absence of TGF $\beta(25 \mathrm{ng} / \mathrm{ml})$ and TNF $\alpha(5 \mathrm{ng} / \mathrm{ml})$. (A) Validation of R2B silencing by western blotting and comparison with siS cells in H295R, HEK293 and MCF-7 cells. (B) A representative dot plot for annexin analysis in H295R cells. Points are the means \pm s.E.M. of three duplicate independent experiments expressed as percentage apoptosis. (C) Results are expressed as the percentage of cells surviving (annexin ${ }^{-} / \mathrm{IP}^{-}$cells) and apoptotic cells (early annexin ${ }^{+} / \mathrm{IP}^{-}$, late apoptosis annexin ${ }^{+} / \mathrm{IP}^{+}$and necrosis annexin ${ }^{-} / \mathrm{IP}^{+}$). $\mathrm{R}^{\mathrm{B}} \mathrm{B}$ invalidation resulted in a larger number of viable cells and a smaller number of apoptotic cells after treatment with TGF $\beta$ and TNF $\alpha$ than for the treated control (siS) H295R cells. Points are the means \pm s. E.M. of three duplicate experiments. ${ }^{\star} P=0.05,{ }^{\star \star} P=0.01$ and ${ }^{\star \star \star} P<0.005$ for H295R cells; ${ }^{\star} P=0.05$ and ${ }^{* \star} P=0.02$ for HEK293 cells; ${ }^{* \star *} P<0.001$ for MCF-7 cells. Comparisons were performed between siS-treated cells versus siS-untreated control cells, and SiR2B-treated or SiR2B-untreated cells versus siS control cells of each treatment. 
phase. 8Cl-cAMP targeting cell cycle phase is cell specific. 8Cl-cAMP acts on MCF-10A HE- and TE-transformed cells, causing these cells to accumulate in the $\mathrm{G}_{0} / \mathrm{G}_{1}$ phase and decreasing the proportion of cells in the $\mathrm{S}$ phase (Ciardiello et al. 1993). 8Cl-cAMP may also affect two phases of the cell cycle, $G_{0} / G_{1}$ and $\mathrm{G}_{2} / \mathrm{M}$, in HL-60 leukaemic cells (Pepe et al. 1991) and primary mouse epidermal keratinocytes (Dransfield et al. 2001).

The effect of 8Cl-cAMP and 8CPT-cAMP on the $\mathrm{S}$ and $\mathrm{G}_{2} / \mathrm{M}$ phases in $\mathrm{H} 295 \mathrm{R}$ cells is parallel to changes in cyclin levels and the activities of cyclin-dependent kinases. The increase in the percentage of H295R cells in the $S$ phase and the early $G_{2}$ phase is linked to the translocation of cyclins $\mathrm{E}$ and $\mathrm{A}$ from the cytosol to the nucleus and the activation of total CDK2 as described previously (Pines \& Hunter 1991, Bailly \& Bornens 1992). 8Cl-cAMP and 8CPT-cAMP allow cells to enter the $\mathrm{G}_{2}$ phase, as shown by the accumulation of cyclin $\mathrm{B}$ in the cytosol. They probably block the H295R cells in the $\mathrm{G}_{2}$ phase by inducing cyclin $\mathrm{B}$ accumulation in the nucleus and decreasing total CDC2 kinase activity. The resulting interruption of mitosis then triggers apoptosis. A direct link has been found between PKA and the molecular mechanisms maintaining cell cycle arrest in the $G_{2}$ phase, with the CDC2-cyclinB complex being kept inactive by the PKA-dependent activation of Weel and inactivation of CDC25 in Xenopus oocytes (Duckworth et al. 2002, Shibuya 2003).

The two selective R2B cAMP analogues trigger apoptosis in H295R cells. This may be a link to their common effect on targeting R2B, decreasing the type 1/type 2 PKA ratio, increasing R2B synthesis and activating PKA, regardless of the effect of 8Cl-cAMP on activating R1A and decreasing its synthesis. The inactivation of R2B by siRNA decreases the basal levels of apoptotic H295R cells and confers resistance to the apoptosis induced by TNF $\alpha$ and TGF $\beta$. These findings are consistent with a role for R2B in apoptosis and the data obtained from the transformed mouse adrenal Y-1 cell line, in which R2B silencing increases proliferation (Mantovani et al. 2008b).

However, PKA type 1 and type 2 in adrenocrotical human H295R cell line do not share the same feature as those in the endocrine tumours, where PKA subunits have compensatory effects and distinct roles (Bossis \& Stratakis 2004, Griffin et al. 2004a,b). The effects of R2B and R1A are not antagonist when inactivated in H295R cells. We have recently shown that inactivation of R1A confers resistance to apoptosis induced by TGFB as does that of R2B (Ragazzon et al. 2009). PKA type 1 and type 2 may have complementary effects on H295R cells. Invalidation of both R1A and R2B confers resistance to apoptosis induced by TNF $\alpha$ in H295R cells. However, they delineate distinct regulation in the expression of pro-apoptotic and apoptotic factors Bax and Bcl2 proteins. Our preliminary results show that the expression of $\mathrm{Bax}$ is decreased and that of $\mathrm{Bcl} 2$ is increased under $\mathrm{TNF} \alpha$ stimulation in R2B-inactivated cells only (data not shown). Activation of the PKA type 1 or type 2 may have the same cellular responses, but it modulates different molecular mechanisms and gene regulations depending on the sensitivity to cAMP concentration and the location of the PKA holoenzyme (Liu et al. 2004b, Tasken \& Aandahl 2004, Dyson et al. 2009). It has been shown by injection of antisense oligonucleotides into the sensory neuron cell body that the two types of kinases have distinct but complementary functions in the production of facilitation at synapses of an identified neuron (Liu et al. 2004b). It has been suggested that PKA type 1 operates in the nucleus to maintain cAMP response element-binding proteindependent gene expression, and PKA type 2 acts at sensory neuron synapses by phosphorylating proteins to enhance the release of a neurotransmitter. Such a distinct function is also reported in steroidogenic tissues for Star gene regulation. Using different selective cAMP analogues, Dyson et al. (2009) have shown that in MA-10 mouse Leydig tumour cells, Stargene expression is more dependent upon PKA type 1, while the post-transcriptional regulation of Star appears to be controlled by PKA type 2 . These experiments delineate the discrete effects that PKA type 1 and type 2 exert on STAR-mediated steroidogenesis, and suggest complementary roles for each subtype in coordinating steroidogenesis.

In conclusion, we have shown that PKA R2B is involved in H295R cell growth. Targeting of PKA R2B, disturbing the balance between PKA isozymes by increasing their expression, influences cell cycle progression by targeting specific cyclins and $\mathrm{G}_{2}$ cell cycle kinases, and induces apoptosis. The silencing of the $R 2 B$ gene confers resistance to apoptosis. Our data associated to those on R1A silencing (Ragazzon et al. 2009) suggest complementary roles of both PKA R1A and PKA R2B in cell apoptosis. Comparative studies of molecular mechanisms involved in apoptosis induced by TGF $\beta$ and TNF $\alpha$ are underway to delineate the effects that PKA type 1 and type 2 exert on the cAMP-PKA signalling pathways involved in adrenocortical tumours.

\section{Declaration of interest}

The authors declare that there is no conflict of interest that could be perceived as prejudicing the impartiality of the research reported.

\section{Funding}

This study was supported by grants from INSERM, CNRS, the Ministère Délégué à la Recherche et des Nouvelles Technologies and the Agence Nationale pour la Recherche (ANR08-GENOPAT-002). $\mathrm{B} \mathrm{R}$ is a recipient of the grants from Fondation pour la Recherche Médicale (FRM) and the Conny-Maeva Foundation. 


\section{Acknowledgements}

We would like to thank Dr Lieberherr Michèle for critical reading of the manuscript. We thank the members of the FACS Core Facility of Institute Cochin, Brigitte Chanaud, Laurence Stouvenel and Martine De Sousa for assistance with FACS analysis.

\section{References}

Bailly E \& Bornens M 1992 Cell biology. Centrosome and cell division. Nature 355 300-301.

Beppu T, Ishida Y, Arai H, Wada T, Uesugi N \& Sasaki K 1994 Identification of S-phase cells with PC10 antibody to proliferating cell nuclear antigen (PCNA) by flow cytometric analysis. Journal of Histochemistry and Cytochemistry 42 1177-1182.

Bertherat J 2001 Protein kinase A in Carney complex: a new example of cAMP pathway alteration in endocrine tumors. European Journal of Endocrinology 144 209-211.

Bertherat J, Groussin L, Sandrini F, Matyakhina L, Bei T, Stergiopoulos S, Papageorgiou T, Bourdeau I, Kirschner LS, Vincent-Dejean C et al. 2003 Molecular and functional analysis of PRKAR1A and it locus (17q22-24) in sporadic adrenocortical tumors: 17q losses, somatic mutations, and protein kinase A expression and activity. Cancer Research 63 5308-5319.

Bossis I \& Stratakis CA 2004 Minireview: PRKAR1A: normal and abnormal functions. Endocrinology 145 5452-5458.

Carney JA, Gordon H, Carpenter PC, Shenoy BV \& Go VL 1985 The complex of myxomas, spotty pigmentation, and endocrine overactivity. Medicine 64 270-283.

Cheadle C, Nesterova M, Watkins T, Barnes KC, Hall JC, Rosen A, Becker KG \& Cho-Chung YS 2008 Regulatory subunits of PKA define an axis of cellular proliferation/differentiation in ovarian cancer cells. BMC Medical Genomics 143.

Cho YS, Kim MK, Tan L, Srivastava R, Agrawal S \& Cho-Chung YS 2002 Protein kinase A RIalpha antisense inhibition of PC3M prostate cancer cell growth: Bcl-2 hyperphosphorylation, Bax up-regulation, and Bad-hypophosphorylation. Clinical Cancer Research 8 607-614.

Cho-Chung YS 2004 Antisense protein kinase A RI alpha-induced tumor reversion: portrait of a microarray. Biochimica et Biophysica Acta 1697 71-79.

Cho-Chung YS \& Nesterova MV 2005 Tumor reversion: protein kinase A isozyme switching. Annals of the New York Academy of Sciences 1058 $76-86$.

Ciardiello F, Pepe S, Bianco C, Baldassarre G, Ruggiero A, Bianco C, Selvam MP, Bianco AR \& Tortora G 1993 Down-regulation of RI alpha subunit of cAMP-dependent protein kinase induces growth inhibition of human mammary epithelial cells transformed by c-Ha-ras and c-erbB-2 proto-oncogenes. International Journal of Cancer 53 438-443.

Dransfield DT, Griner RD, Ray S, Keskintepe M \& Bollag WB 2001 8-Cl-adenosine induces growth arrest without differentiation of primary mouse epidermal keratinocytes. Journal of Investigative Dermatology 117 1588-1593.

Duckworth BC, Weaver JS \& Ruderman JV $2002 \mathrm{G}_{2}$ arrest in Xenopus oocytes depends on phosphorylation of cdc 25 by protein kinase $\mathrm{A}$. PNAS 99 16794-16799.

Dyson MT, Kowalewski MP, Manna PR \& Stocco DM 2009 The differential regulation of steroidogenic acute regulatory protein-mediated steroidogenesis by type I and type II PKA in MA-10 cells. Molecular and Cellular Endocrinology 300 94-103.

Gazdar AF, Oie HK, Shackleton CH, Chen TR, Triche TJ, Myers CE, Chrousos GP, Brennan MF, Stein CA \& La Rocca RV 1990 Establishment and characterization of a human adrenocortical carcinoma cell line that expresses multiple pathways of steroid biosynthesis. Cancer Research 50 5488-5496.
Griffin KJ, Kirschner LS, Matyakhina L, Stergiopoulos S,

Robinson-White A, Lenherr S, Weinberg FD, Claflin E, Meoli E, Cho-Chung YS et al. 2004a Down-regulation of regulatory subunit type $1 \mathrm{~A}$ of protein kinase A leads to endocrine and other tumors. Cancer Research 64 8811-8815.

Griffin KJ, Kirschner LS, Matyakhina L, Stergiopoulos SG, Robinson-White A, Lenherr SM, Weinberg FD, Claflin ES, Batista D, Bourdeau I et al. 2004b A transgenic mouse bearing an antisense construct of regulatory subunit type 1A of protein kinase A develops endocrine and other tumours: comparison with Carney complex and other PRKAR1A induced lesions. Journal of Medical Genetics 41 923-931.

Groussin L, Massias JF, Bertagna X \& Bertherat J 2000 Loss of expression of the ubiquitous transcription factor cAMP response element-binding protein (CREB) and compensatory overexpression of the activator CREMtau in the human adrenocortical cancer cell line H295R. Journal of Clinical Endocrinology and Metabolism 85 345-354.

Groussin L, Kirschner LS, Vincent-Dejean C, Perlemoine K, Jullian E, Delemer B, Zacharieva S, Pignatelli D, Carney JA, Luton JP et al. $2002 a$ Molecular analysis of the cyclic AMP-dependent protein kinase A (PKA) regulatory subunit 1A (PRKAR1A) gene in patients with Carney complex and primary pigmented nodular adrenocortical disease (PPNAD) reveals novel mutations and clues for pathophysiology: augmented PKA signaling is associated with adrenal tumorigenesis in PPNAD. American Journal of Human Genetics 71 1433-1442.

Groussin L, Jullian E, Perlemoine K, Louvel A, Leheup B, Luton JP, Bertagna X \& Bertherat J 2002b Mutations of the PRKAR1A gene in Cushing's syndrome due to sporadic primary pigmented nodular adrenocortical disease. Journal of Clinical Endocrinology and Metabolism 87 4324-4329.

Groussin L, Horvath A, Jullian E, Boikos S, Rene-Corail F, Lefebvre H, Cephise-Velayoudom FL, Vantyghem MC, Chanson P, Conte-Devolx B et al. 2006 A PRKAR1A mutation associated with primary pigmented nodular adrenocortical disease in 12 kindreds. Journal of Clinical Endocrinology and Metabolism 91 1943-1949.

Horvath A, Boikos S, Giatzakis C, Robinson-White A, Groussin L, Griffin KJ, Stein E, Levine E, Delimpasi G, Hsiao HP et al. 2006 A genome-wide scan identifies mutations in the gene encoding phosphodiesterase 11A4 (PDE11A) in individuals with adrenocortical hyperplasia. Nature Genetics 38 794-800.

Horvath A, Giatzakis C, Tsang K, Greene E, Osorio P, Boikos S, Libe R, Patronas Y, Robinson-White A, Remmers E et al. 2008 A cAMP-specific phosphodiesterase (PDE8B) that is mutated in adrenal hyperplasia is expressed widely in human and mouse tissues: a novel PDE8B isoform in human adrenal cortex. European Journal of Human Genetics 16 1245-1253.

Jaroenporn S, Furuta C, Nagaoka K, Watanabe G \& Taya K 2008 Comparative effects of prolactin versus ACTH, estradiol, progesterone, testosterone, and dihydrotestosterone on cortisol release and proliferation of the adrenocortical carcinoma cell line H295R. Endocrine 33 205-209.

Kim SN, Kim SG, Park JH, Lee MA, Park SD, Cho-Chung YS \& Hong SH 2000 Dual anticancer activity of 8-Cl-cAMP: inhibition of cell proliferation and induction of apoptotic cell death. Biochemical and Biophysical Research Communications 273 404-410.

Kim SN, Ahn YH, Kim SG, Park SD, Cho-Chung YS \& Hong SH 2001 8-Cl-cAMP induces cell cycle-specific apoptosis in human cancer cells. International Journal of Cancer 93 33-41.

Kirschner LS, Sandrini F, Monbo J, Lin JP, Carney JA \& Stratakis CA 2000 Genetic heterogeneity and spectrum of mutations of the PRKAR1A gene in patients with the carney complex. Human Molecular Genetics 9 3037-3046.

Knutsen HK, Reinton N, Tasken KA, Hansson V \& Eskild W 1996 Regulation of protein kinase A subunits by cyclic adenosine 
$3^{\prime}, 5^{\prime}$-monophosphate in a mouse Sertoli cell line (MSC-1): induction of RII beta messenger ribonucleic acid is independent of continuous protein synthesis. Biology of Reproduction 55 5-10.

Koopman G, Reutelingsperger CP, Kuijten GA, Keehnen RM, Pals ST \& van Oers MH 1994 Annexin V for flow cytometric detection of phosphatidylserine expression on B cells undergoing apoptosis. Blood 84 1415-1420.

Lange-Carter CA, Vuillequez JJ \& Malkinson AM 1993 8-Chloroadenosine mediates 8-chloro-cyclic AMP-induced down-regulation of cyclic AMP-dependent protein kinase in normal and neoplastic mouse lung epithelial cells by a cyclic AMP-independent mechanism. Cancer Research 53 393-400.

Lania AG, Mantovani G, Ferrero S, Pellegrini C, Bondioni S, Peverelli E, Braidotti P, Locatelli M, Zavanone ML, Ferrante E et al. 2004 Proliferation of transformed somatotroph cells related to low or absent expression of protein kinase a regulatory subunit 1A protein. Cancer Research 64 9193-9198.

Libe R, Fratticci A, Coste J, Tissier F, Horvath A, Ragazzon B, Rene-Corail F, Groussin L, Bertagna X, Raffin-Sanson ML et al. 2008 Phosphodiesterase 11A (PDE11A) and genetic predisposition to adrenocortical tumors. Clinical Cancer Research 14 4016-4024.

Liu J, Li XD, Ora A, Heikkila P, Vaheri A \& Voutilainen R $2004 a$ cAMP-dependent protein kinase activation inhibits proliferation and enhances apoptotic effect of tumor necrosis factor-alpha in NCI-H295R adrenocortical cells. Journal of Molecular Endocrinology 33 511-522.

Liu J, Hu JY, Schacher S \& Schwartz JH $2004 b$ The two regulatory subunits of aplysia cAMP-dependent protein kinase mediate distinct functions in producing synaptic plasticity. Journal of Neuroscience 24 2465-2474.

Livesey SA, Kemp BE, Re CA, Partridge NC \& Martin TJ 1982 Selective hormonal activation of cyclic AMP-dependent protein kinase isoenzymes in normal and malignant osteoblasts. Journal of Biological Chemistry 257 14983-14987.

Mantovani G, Lania AG, Bondioni S, Peverelli E, Pedroni C, Ferrero S, Pellegrini C, Vicentini L, Arnaldi G, Bosari S et al. 2008a Different expression of protein kinase A (PKA) regulatory subunits in cortisol-secreting adrenocortical tumors: relationship with cell proliferation. Experimental Cell Research 314 123-130.

Mantovani G, Bondioni S, Lania AG, Rodolfo M, Peverelli E, Polentarutti N, Veliz Rodriguez T, Ferrero S, Bosari S, Beck-Peccoz P et al. $2008 b$ High expression of PKA regulatory subunit 1A protein is related to proliferation of human melanoma cells. Oncogene $\mathbf{2 7}$ 1834-1843.

McDaid HM, Cairns MT, Atkinson RJ, McAleer S, Harkin DP, Gilmore P \& Johnston PG 1999 Increased expression of the RIalpha subunit of the cAMP-dependent protein kinase A is associated with advanced stage ovarian cancer. British Journal of Cancer 79 933-939.

Mikhaylova IV, Kuulasmaa T, Jaaskelainen J \& Voutilainen R 2007 Tumor necrosis factor-alpha regulates steroidogenesis, apoptosis, and cell viability in the human adrenocortical cell line NCI-H295R. Endocrinology 148 386-392.

Miller WR, Hulme MJ, Cho-Chung YS \& Elton RA 1993 Types of cyclic AMP binding proteins in human breast cancers. European Journal of Cancer 29A 989-991.

Neary CL, Nesterova M, Cho YS, Cheadle C, Becker KG \& Cho-Chung YS 2004 Protein kinase A isozyme switching: eliciting differential cAMP signaling and tumor reversion. Oncogene 23 8847-8856.

Nesterova M \& Cho-Chung YS 2000 Oligonucleotide sequence-specific inhibition of gene expression, tumor growth inhibition, and modulation of cAMP signaling by an RNA-DNA hybrid antisense targeted to protein kinase A RIalpha subunit. Antisense $\mathcal{E}$ Nucleic Acid Drug Development 10 423-433.

Nesterova M, Noguchi K, Park YG, Lee YN \& Cho-Chung YS 2000 Compensatory stabilization of RIIbeta protein, cell cycle deregulation, and growth arrest in colon and prostate carcinoma cells by antisense-directed down-regulation of protein kinase A RIalpha protein. Clinical Cancer Research 6 3434-3441.
Nesterova M, Bossis I, Wen F, Horvath A, Matyakhina L \& Stratakis CA 2008 An immortalized human cell line bearing a PRKAR1Ainactivating mutation: effects of overexpression of the wild-type Allele and other protein kinase A subunits. Journal of Clinical Endocrinology and Metabolism 93 565-571.

Pepe S, Tortora G, Noguchi PD, Marti GE, Washington GC \& Cho-Chung YS 1991 Effects of 8-chloroadenosine $3^{\prime}, 5^{\prime}$-monophosphate and N6-benzyl-cyclic adenosine $5^{\prime}$-monophosphate on cell cycle kinetics of HL-60 leukemia cells. Cancer Research 51 6263-6267.

Pines J \& Hunter T 1991 Human cyclins A and B1 are differentially located in the cell and undergo cell cycle-dependent nuclear transport. Journal of Cell Biology 115 1-17.

Porter DC, Zhang N, Danes C, McGahren MJ, Harwell RM, Faruki S \& Keyomarsi K 2001 Tumor-specific proteolytic processing of cyclin E generates hyperactive lower-molecular-weight forms. Molecular and Cellular Biology 21 6254-6269.

Ragazzon B, Cazabat L, Rizk-Rabin M, Assie G, Groussin L, Fierrard H, Perlemoine K, Martinez A \& Bertherat J 2009 Inactivation of the Carney complex gene 1 (protein kinase A regulatory subunit 1A) inhibits SMAD3 expression and TGF beta-stimulated apoptosis in adrenocortical cells. Cancer Research 69 7278-7284.

Rainey WE, Bird IM \& Mason I 1994 The NCI-H295 cell line: a pluripotent model for human adrenocortical studies. Molecular and Cellular Endocrinology 100 45-50.

Rainey WE, Saner K \& Schimmer BP 2004 Adrenocortical cell lines. Molecular and Cellular Endocrinology 228 23-38.

Rizk-Rabin M, Assie G, Rene-Corail F, Perlemoine K, Hamzaoui H, Tissier F, Lieberherr M, Bertagna X, Bertherat J \& Bouizar Z 2008 Differential expression of parathyroid hormone-related protein in adrenocortical tumors: autocrine/paracrine effects on the growth and signaling pathways in H295R cells. Cancer Epidemiology, Biomarkers \& Prevention 17 2275-2285.

Robinson-White AJ, Hsiao HP, Leitner WW, Greene E, Bauer A, Krett NL, Nesterova M \& Stratakis CA 2008 Protein kinase A-independent inhibition of proliferation and induction of apoptosis in human thyroid cancer cells by 8-Cl-adenosine. Journal of Clinical Endocrinology and Metabolism 93 1020-1029.

Rohlff C, Clair T \& Cho-Chung YS 1993 8-Cl-cAMP induces truncation and down-regulation of the RI alpha subunit and up-regulation of the RII beta subunit of cAMP-dependent protein kinase leading to type II holoenzyme-dependent growth inhibition and differentiation of HL-60 leukemia cells. Journal of Biological Chemistry 268 $5774-5782$.

Rosenberg D, Groussin L, Bertagna X \& Bertherat J 2002 cAMP pathway alterations from the cell surface to the nucleus in adrenocortical tumors. Endocrine Research 28 765-775.

Shibuya EK $2003 \mathrm{G}_{2}$ cell cycle arrest - a direct link between PKA and Cdc25C. Cell Cycle 2 39-41.

Stoika RS, Yakymovych IA, Kashchak NI, Boyko MM, Korynevska AV, Klyuchyvska OY, Shafranska GI, Yakymovych MY, Zhylchuk VY, Kudryavets YY et al. 2008 Effect of anticancer drugs on production of transforming growth factor and expression of p53 and Bcl-2 proteins by MCF-7 and T47D cell lines of human breast carcinoma. Experimental Oncology 30 35-41.

Stubbs AP, Lalani EN, Stamp GW, Hurst H, Abel P \& Waxman J 1996 Second messenger up-regulation of androgen receptor gene transcription is absent in androgen insensitive human prostatic carcinoma cell lines, PC-3 and DU-145. FEBS Letters 383 237-240.

Tasken K \& Aandahl EM 2004 Localized effects of cAMP mediated by distinct routes of protein kinase A. Physiological Reviews $\mathbf{8 4}$ 137-167.

Uzbekov RE 2004 Analysis of the cell cycle and a method employing synchronized cells for study of protein expression at various stages of the cell cycle. Biochemistry 69 485-496. 
Veugelers M, Wilkes D, Burton K, McDermott DA, Song Y, Goldstein MM, La Perle K, Vaughan CJ, O'Hagan A, Bennett KR et al. 2004 Comparative PRKAR1A genotype-phenotype analyses in humans with Carney complex and prkarla haploinsufficient mice. PNAS 101 14222-14227.

Vincent-Dejean C, Cazabat L, Groussin L, Perlemoine K, Fumey G, Tissier F, Bertagna X \& Bertherat J 2008 Identification of a clinically homogenous subgroup of benign cortisol-secreting adrenocortical tumors characterized by alterations of the protein kinase A (PKA) subunits and high PKA activity. European Journal of Endocrinology 158 829-839.
Yamasaki H, Mizusawa N, Nagahiro S, Yamada S, Sano T, Itakura M \& Yoshimoto K $2003 \mathrm{GH}$-secreting pituitary adenomas infrequently contain inactivating mutations of PRKAR1A and LOH of 17q23-24. Clinical Endocrinology 58 464-470.

Received in final form 8 March 2010

Accepted 17 March 2010

Made available online as an Accepted Preprint

17 March 2010 